\title{
Protein level affects the relative lysine requirement of growing rainbow trout (Oncorhynchus mykiss) fry
}

\author{
Noelie Bodin ${ }^{1}$, Bernadette Govaerts ${ }^{2}$, Tarik Abboudi ${ }^{1}$, Christel Detavernier ${ }^{3}$, Sarah De Saeger ${ }^{3}$, \\ Yvan Larondelle ${ }^{1}$ and Xavier Rollin ${ }^{1 *}$ \\ ${ }^{1}$ Laboratoire de Pisciculture M. Huet, Unité de Biochimie de la Nutrition, Université catholique de Louvain, Route de Blocry 2 , \\ B-1348 Louvain-la-Neuve, Belgium \\ ${ }^{2}$ Institut de statistique, Université catholique de Louvain, Voie du roman pays 20, B-1348 Louvain-la-Neuve, Belgium \\ ${ }^{3}$ Laboratorium voor Bromatologie, Universiteit Gent, Harelbekestraat 72, B-9000, Gent, Belgium
}

(Received 18 April 2008 - Revised 9 October 2008 - Accepted 13 October 2008 - First published online 13 January 2009)

\begin{abstract}
The effect of two digestible protein levels (310 and $469 \mathrm{~g} / \mathrm{kg} \mathrm{DM}$ ) on the relative lysine (Lys; $\mathrm{g}$ Lys $/ \mathrm{kg}$ DM or $\mathrm{g} \mathrm{Lys} / 100 \mathrm{~g}$ protein) and the absolute Lys (g Lys intake/ $\mathrm{kg}^{075}$ per d) requirements was studied in rainbow trout fry using a dose-response trial. At each protein level, sixteen isoenergetic (22-23 MJ digestible energy/kg DM) diets were tested, involving a full range $(2-70 \mathrm{~g} / \mathrm{kg} \mathrm{DM})$ of sixteen Lys levels. Each diet was given to one group of sixty rainbow trout fry (mean initial body weight $0.78 \mathrm{~g}$ ) reared at $15^{\circ} \mathrm{C}$ for 31 feeding d. The Lys requirements were estimated based on the relationships between weight, protein, and Lys gains $\left(\mathrm{g} / \mathrm{kg}^{0.75}\right.$ per d) and Lys concentration $(\mathrm{g} / \mathrm{kg}$ DM or g/100 g protein) or Lys intake $\left(\mathrm{g} / \mathrm{kg}^{075}\right.$ per $\left.\mathrm{d}\right)$, using the broken-line model (BLM) and the non-linear four-parameter saturation kinetics model (SKM-4). Both the model and the response criterion chosen markedly impacted the relative Lys requirement. The relative Lys requirement for Lys gain of rainbow trout estimated with the BLM (and SKM-4 at $90 \%$ of the maximum response) increased from $16.8(19.6) \mathrm{g} / \mathrm{kg}$ DM at a low protein level to 23.4 (24.5) $\mathrm{g} / \mathrm{kg}$ DM at a high protein level. However, the dietary protein content affected neither the absolute Lys requirement nor the relative Lys requirement expressed as $\mathrm{g}$ Lys/100 g protein nor the Lys requirement for maintenance $\left(21 \mathrm{mg} \mathrm{Lys} / \mathrm{kg}^{0.75}\right.$ per d).
\end{abstract}

Growth requirements: Lysine requirement: Protein level: Rainbow trout fry

Precise indispensable amino acid (AA) requirement values are necessary for elaborating balanced aquafeeds that ensure both cost-effectiveness and minimal environmental impact. This necessity has been heightened by the increasing use of plant protein sources to replace fishmeal in aquafeeds. Large variations in relative indispensable AA requirement estimates for different salmonid species and within species alike still subsist in the literature ${ }^{(1)}$. Even for lysine (Lys), which is often the first limiting AA in plant proteins, the published relative requirement estimates vary greatly, from 1.3 to $2.9 \%$ of the $\operatorname{diet}^{(1)}$. Plausible causes of the variation are the units used to express the requirement ${ }^{(2-4)}$, diet composition ${ }^{(4)}$, laboratory variance $^{(5)}$, overfeeding ${ }^{(2,3)}$, response criterion ${ }^{(1)}$ and experimental design, statistical analysis and model choice ${ }^{(6)}$. Basal diet composition $^{(1)}$ and, more specifically, the influence of dietary protein level on the requirement of the first limiting indispensable AA has not yet been examined for fish. The implications are far-reaching, especially when one considers that diet formulators may choose to increase or decrease the dietary protein level for a wide variety of reasons. They may wish to achieve maximum growth performance, decrease environmental impact, increase cost-effectiveness, or to adapt the diet to the life stage of the fish. Also, the protein level in the diet may be affected by the use of large amounts of plant protein sources which may contain lower protein concentrations than fishmeal.

In warm-blooded terrestrial animals, it has been reported for a long time that relative AA requirements are related to dietary protein concentration $^{(7-17)}$. In general, the requirement for an AA expressed as a percentage of the diet increased as dietary protein concentration increased up to the level of protein required for maximum growth ${ }^{(18)}$. For instance, Brinegar et al. ${ }^{(9)}$ showed that the mimimum level of Lys which produced the maximum weight gain, considered as the Lys requirement, in swine, was $6 \mathrm{~g} / \mathrm{kg}$ in a $10.6 \%$ protein diet and $12 \mathrm{~g} / \mathrm{kg}$ in a $22 \%$ protein diet. This difference in the requirements almost disappeared when the requirements were expressed in terms of their proportion to the protein in the diets. However, the AA requirement expressed as a percentage of the diet has also been reported to remain constant or even to decrease slightly when expressed as a percentage of dietary protein ${ }^{(11-14,19-21)}$. This situation is usually observed under conditions of optimal and supra-optimal protein intakes or concentrations in the diets ${ }^{(14)}$. For example,

Abbreviations: AA, amino acid; BLM, broken-line model; HP, high protein; LP, low protein; Lys, lysine; MBW, metabolic body weight; PPV, protein productive value; SKM-4, saturation kinetics model with four parameters.

* Corresponding author: Dr Xavier Rollin, fax + 32 10459846, email xavier.rollin@uclouvain.be 
Bressani \& Mertz ${ }^{(12)}$ demonstrated that the Lys requirement expressed as a percentage of the diet remained essentially constant in the range of $16-40 \%$ protein, i.e. above optimal protein level for rats ${ }^{(22)}$.

The main objective of the present study was to determine the effect of the dietary protein level on the relative and absolute Lys requirements of rainbow trout fry. Two secondary objectives were to examine the influence of the model choice and the response criterion on the Lys requirement estimate. Both a linear model and a non-linear model were fitted to the data to estimate the Lys requirements. The broken-line model (BLM) of Robbins et al. ${ }^{(23)}$ was chosen because it is the most widely used method of evaluating dose-response data in nutrient requirement studies in fish $^{(6)}$ including Lys $^{(2)}$. On the other hand, the saturation kinetics model ${ }^{(24)}$ with four parameters (SKM-4) was also selected in the present study because we used a wide range ${ }^{(25)}$ of Lys concentrations of about three times the requirement without observing any inhibition in the response of trout fry ${ }^{(1,6,26)}$. The main response criteria studied were gains in body weight, protein and Lys. The total Lys requirement was expressed in both absolute (g Lys/kg metabolic body weight (MBW) per d) and in relative (g Lys/kg dry diet (DM) or $\mathrm{g} / 100 \mathrm{~g}$ protein) terms.

\section{Materials and methods}

Two experiments were undertaken. The first was designed to establish the response of protein and Lys gains to Lys intake for a wide range of Lys intakes at two different protein levels. The second experiment was a digestibility trial performed with two diets obtained by blending diets of experiment one. The two diets differed in their protein level and contained the optimal Lys level found with the first experiment. The second experiment was necessary to evaluate the digestibility of proteins and energy in the two basal diets and the relative and absolute Lys requirements on a digestible basis.

\section{Experimental diets}

Thirty-two isoenergetic experimental diets were formulated to contain sixteen Lys levels and two protein levels, giving a $16 \times 2$ factorial design. For the low-protein (LP) and high-protein (HP) diets the targeted crude protein levels were of 300 and $450 \mathrm{~g}$ crude protein $/ \mathrm{kg}$ DM, respectively. For diets LP0 to LP15, the targeted Lys levels in $\mathrm{g} / \mathrm{kg}$ diet DM were of $2,4,6,8,10,12,14,16,18,20,22,24,26$, 33, 40, 47 and for diets HP0 to HP15, the total targeted Lys levels in $\mathrm{g} / \mathrm{kg}$ diet $\mathrm{DM}$ were of $2,6,9,12,15,18,21,24$, $27,30,33,36,39,50,60,70$. The AA diet profile followed the National Research Council recommendations ${ }^{(27)}$, except for Lys. Wheat gluten provided the main protein source. A mixture of non-essential crystalline AA was added in order to compensate for the reduction in Lys and to maintain the same digestible $\mathrm{N}$ and total crystalline AA levels for all diets. The experimental diets were produced as previously reported $^{(28)}$. In particular, the crystalline AA mixtures were coated with $1 \%$ agar, as described by Mambrini \& Kaushik $^{(29)}$, to hinder leakage, delay its digestive absorption and optimise its use for protein accretion. After extrusion, the experimental diets were stored at $-20^{\circ} \mathrm{C}$. The ingredients and proximate compositions of the diets are shown in Tables 1 and 2. The AA composition was analysed once for the following eight diets: LP0, LP5, LP10, LP15, HP0, HP5, HP10 and HP15 (Table 3). Because the AA levels in the eight analysed diets were very close to the formulated levels, it followed that the diets had the formulated concentration of all AA and in particular of Lys.

\section{Fish and feeding}

The Animal Welfare Commission of the Université catholique de Louvain approved the experiment in accordance with the EC directive concerning vertebrate laboratory animals.

Rainbow trout eyed embryonic eggs of domesticated origin were supplied to our laboratory hatchery (M. Huet Fish Culture Laboratory, Université catholique de Louvain, Louvain-laNeuve, Belgium) by a commercial fish farm (La Fontaine aux Truites, Gérouville, Belgium) and then reared to the

Table 1. Composition of the low-protein (LP) and high-protein (HP) experimental diets used for determining the effect of diet digestible protein on lysine (Lys) requirements and retention efficiencies in rainbow trout fry

(Mean values and standard deviations)

\begin{tabular}{|c|c|c|c|c|}
\hline \multirow[t]{2}{*}{ Diets... } & \multicolumn{2}{|c|}{ LP0 to LP15 } & \multicolumn{2}{|c|}{ HP0 to HP15 } \\
\hline & Mean & SD & Mean & SD \\
\hline \multicolumn{5}{|l|}{ Components ( $\mathrm{g} / \mathrm{kg}$ diet) } \\
\hline Wheat gluten meal§ & $127 \cdot 5$ & & 192 & \\
\hline L-Amino acid mixture\| & $209 \cdot 1$ & & 312.5 & \\
\hline Cod liver oilף & 205 & & 205 & \\
\hline Glucose ${ }^{\star \star}$ & $148 \cdot 4$ & & 0 & \\
\hline Dextrin§ & 180 & & $160 \cdot 5$ & \\
\hline Soya lecithint† & 40 & & 40 & \\
\hline 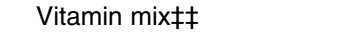 & 10 & & 10 & \\
\hline Mineral mix§§ & 40 & & 40 & \\
\hline Agar§ & 10 & & 10 & \\
\hline Carboxymethylcellulose§ & 20 & & 20 & \\
\hline$\alpha$-Cellulose§ & 10 & & 10 & \\
\hline \multicolumn{5}{|c|}{ Analysed chemical composition and digestible values } \\
\hline DM (g/kg diet) |\|\| & $919 \cdot 5$ & $4 \cdot 2$ & $932 \cdot 7$ & $8 \cdot 1$ \\
\hline Crude protein (g/kg DM) ๆ ๆ & $316 \cdot 4$ & 3.4 & $474 \cdot 7$ & 1.4 \\
\hline $\mathrm{DP}(\mathrm{g} / \mathrm{kg} \mathrm{DM})$ ๆ ๆ & $309 \cdot 9$ & 0.6 & 468.8 & 0.2 \\
\hline Ash (g/kg DM) \|\| & $31 \cdot 1$ & $3 \cdot 2$ & $32 \cdot 3$ & $1 \cdot 3$ \\
\hline Energy (kJ/g DM) १ ๆ & $23 \cdot 7$ & 0.04 & $24 \cdot 2$ & 0.06 \\
\hline $\mathrm{DE}(\mathrm{kJ} / \mathrm{g} \mathrm{DM}) \boldsymbol{\|}$ & $21 \cdot 8$ & $0 \cdot 15$ & $23 \cdot 0$ & 0.04 \\
\hline $\mathrm{DP} / \mathrm{DE}(\mathrm{g} / \mathrm{kJ})$ & $14 \cdot 2$ & & $20 \cdot 4$ & \\
\hline
\end{tabular}

$\mathrm{DE}$; digestible energy; $\mathrm{DP}$, digestible protein.

$\S$ Sigma (St Louis, MO, USA): wheat gluten meal g5004; dextrin (from corn) d2256; agar a5306; carboxymethylcellulose c4888; $\alpha$-cellulose c8002.

\| For composition, see Table 2.

१ Federa (Brussels, Belgium).

${ }^{\star *}$ Merck (Darmstadt, Germany) 8337.5000.

†† Cereal (Beerzel, Belgium).

$\ddagger \ddagger$ Supplied the following (to provide $\mathrm{g} / \mathrm{kg}$ premix): retinyl acetate $(1500000 \mathrm{IU} / \mathrm{g})$, 0.67; ascorbic acid, 120 ; cholecalciferol $(4000000 \mathrm{IU} / \mathrm{g}), 0.1$; tocopheryl acetate $(1000 \mathrm{IU} / \mathrm{g})$, 34.2; phylloquinone, 2.2; thiamin, $5 \cdot 6$; riboflavin, 12; pyridoxine, 4.5; calcium-panthotenate, 14.1; $p$-aminobenzoic acid, 40; vitamin $B_{12}, 0.03$; niacin, 30; biotin, 0.1; choline chloride, 300; folic acid, 1.5; inositol, 50; canthaxanthin, 7; butylated hydroxytoluene, 1.5 ; butylated hydroxyanisole, 1.5; $\alpha$-cellulose, 323.8.

$\S \S$ Supplied the following (to provide $\mathrm{g} / \mathrm{kg}$ mixture): $\mathrm{CaHPO}_{4} \cdot 2 \mathrm{H}_{2} \mathrm{O}, 117.28$; $\mathrm{CaHPO}_{4}, 165.28 ; \mathrm{Ca}\left(\mathrm{PO}_{4}\right)_{2} \cdot \mathrm{H}_{2} \mathrm{O}, 236.03 ; \mathrm{NaHCO}_{3}, 100.44 ; \mathrm{Na}_{2} \mathrm{SO}_{3}, 0.011 ; \mathrm{KCl}$, $108 \cdot 61 ; \mathrm{NaCl}, 143 \cdot 49 ; \mathrm{KI}, 0.218 ; \mathrm{MgCl}_{2}, 101 \cdot 88 ; \mathrm{MnSO}_{4} \cdot \mathrm{H}_{2} \mathrm{O}, 1 \cdot 75 ; \mathrm{FeSO}_{4} \cdot 7 \mathrm{H}_{2}$. $\mathrm{O}, 13 \cdot 51 ; \mathrm{CuSO}_{4} \cdot 5 \mathrm{H}_{2} \mathrm{O}, 0.435 ; \mathrm{ZnSO}_{4} \cdot 7 \mathrm{H}_{2} \mathrm{O}, 10.88$

|||| Growth trial diets LP 0, 510 and 15 and HP 0, 510 and 15 were analysed in duplicates.

११ Digestibility trial diets LP and HP (26 $\mathrm{g} \mathrm{Lys} / \mathrm{kg} \mathrm{DM}$ ) were tested or analysed in duplicates. 
Table 2. Composition of $L$-amino acid mixtures $(\mathrm{g} / \mathrm{kg} \mathrm{DM})$ used in the low-protein (LP) and high-protein (HP) experimental diets§

\begin{tabular}{|c|c|c|}
\hline Diets... & LP0 to LP15 & HP0 to HP15 \\
\hline Arg & $16 \cdot 6$ & $25 \cdot 3$ \\
\hline His & $7 \cdot 3$ & $11 \cdot 2$ \\
\hline Ile & $9 \cdot 8$ & $15 \cdot 0$ \\
\hline Leu & $16 \cdot 8$ & $25 \cdot 7$ \\
\hline Lys.HCl & $0-56.6$ & $0-84.9$ \\
\hline Met & $9 \cdot 3$ & $14 \cdot 2$ \\
\hline Cys & 0 & 0 \\
\hline Phe & 8.4 & $12 \cdot 8$ \\
\hline Tyr & $7 \cdot 3$ & $11 \cdot 1$ \\
\hline Thr & $12 \cdot 3$ & $18 \cdot 8$ \\
\hline Trp & 2.9 & 4.5 \\
\hline Val & 11.9 & $18 \cdot 2$ \\
\hline Ala & $10 \cdot 5-18 \cdot 3$ & $16 \cdot 2-27 \cdot 9$ \\
\hline Asp & $7 \cdot 9-13 \cdot 8$ & $12 \cdot 3-21 \cdot 1$ \\
\hline Asn. $\mathrm{H}_{2} \mathrm{O}$ & $9 \cdot 8-15 \cdot 7$ & $15 \cdot 1-24 \cdot 0$ \\
\hline Glu & $1.4-9.9$ & $0.2-12.9$ \\
\hline Gln & $1.4-9.9$ & $0.2-12.9$ \\
\hline Gly & $12 \cdot 2-21 \cdot 5$ & $8 \cdot 9-32 \cdot 7$ \\
\hline Pro & $1 \cdot 4-7 \cdot 2$ & $0.06-8.7$ \\
\hline Ser & $4 \cdot 6-10 \cdot 1$ & $7 \cdot 2-15 \cdot 5$ \\
\hline Sum & $208 \cdot 7-209 \cdot 1$ & $311 \cdot 9-312.5$ \\
\hline
\end{tabular}

$\S$ Ajinomoto Ltd (Tokyo, Japan).

beginning of the experiment. After hatching, the fry were kept in a single tank and fed, to slight excess by an automatic feeder, an AquaBio Joosen-Luyckx (Turnhout, Belgium) commercial diet up to the start of the experiment. The daily mortality rate always stayed below $0 \cdot 1 \%$.

After $36 \mathrm{~h}$ of feed deprivation and immediately prior to the experimental phase, the rainbow trout fry (mean initial body weight 0.78 (SD 0.01) g) were randomly distributed between thirty-four indoor aquaria $(0.4 \times 0.24 \times 0.2 \mathrm{~m})$ of 15 litres. There were sixty fish per aquarium and each experimental diet was randomly allocated to one aquarium $(n 1)$. Thus, for each dietary protein level (LP and HP), there was one aquarium for every tested dietary Lys concentration. To serve as initial samples, the fish of two randomly chosen aquaria were weighed, anaesthetised with excess ethylene glycol monophenyl ether, counted and kept frozen $\left(-20^{\circ} \mathrm{C}\right)$ until chemical analysis. Optimum conditions were maintained throughout the entire experiment as the aquaria were continuously aerated and supplied with freshwater $(11 / \mathrm{min})$ at $14 \cdot 5-15 \cdot 5^{\circ} \mathrm{C}$. The fish were exposed to a photoperiod of $8 \mathrm{~h}$ of darkness and $16 \mathrm{~h}$ of light (100 lux measured at the water surface).

The fish were fed for $31 \mathrm{~d}$, twice daily, at 09.00 and 22.00 hours, for three periods of 11,10 and $10 \mathrm{~d}$ each. The duration of the experiment was chosen to ensure a tripling in body weight for the groups receiving a slightly sub-optimal Lys level (LP6 and HP6 and above). The fish were carefully fed manually to apparent satiety, which allowed the amount of feed distributed to each aquarium to be recorded after each meal. During the meals, it was ensured that the fish ate the pellets within a maximum of $15 \mathrm{~s}$ of contact with the water in order to minimise the leaching of nutrients into the water. Mortality, if present, was recorded daily. At the end of the experiment and after $72 \mathrm{~h}$ of food deprivation, the fish in each aquarium were weighed together, anaesthetised with excess ethylene glycol monophenyl ether, counted and frozen $\left(-20^{\circ} \mathrm{C}\right)$. Initial and final fish whole bodies were freeze-dried, homogenised (Grindomix GM 200; Retsch, Haan, Germany) and kept frozen $\left(-20^{\circ} \mathrm{C}\right)$ until chemical analysis.

Table 3. Crude protein ( $\mathrm{g}$ nitrogen $\times 6 \cdot 25 / \mathrm{kg}$ ) and amino acid $(\mathrm{g} / \mathrm{kg} \mathrm{DM})$ content analysed in reference diets for rainbow trout fry

\begin{tabular}{|c|c|c|c|c|c|c|c|c|c|}
\hline Diets... & LPO & LP5 & LP10 & LP15 & HPO & HP5 & HP10 & HP15 & Recommended values§ \\
\hline $\begin{array}{l}\text { g N } \times 6 \cdot 25 / \mathrm{kg} \\
\mathrm{g} / \mathrm{kg} \mathrm{DM}\end{array}$ & 323 & 313 & 319 & 302 & 477 & 474 & 477 & 458 & \\
\hline Arg & 21.3 & $22 \cdot 1$ & $21 \cdot 1$ & $19 \cdot 4$ & $32 \cdot 1$ & 39.4 & 31.9 & 29.0 & 15 \\
\hline His & $10 \cdot 1$ & $10 \cdot 9$ & $10 \cdot 4$ & 9.5 & $15 \cdot 1$ & $18 \cdot 2$ & $15 \cdot 0$ & $15 \cdot 2$ & 7 \\
\hline Ile & 14.5 & 14.9 & 14.5 & $13 \cdot 4$ & $20 \cdot 2$ & 24.9 & 21.4 & $20 \cdot 9$ & 9 \\
\hline Leu & $22 \cdot 3$ & $22 \cdot 4$ & $23 \cdot 9$ & 21.4 & $24 \cdot 1$ & 33.4 & $30 \cdot 2$ & 28.5 & 14 \\
\hline Lys & 1.9 & 13.5 & $23 \cdot 3$ & 44.4 & $2 \cdot 4$ & $22 \cdot 9$ & $33 \cdot 8$ & $73 \cdot 6$ & 18 \\
\hline Met & 11.4 & 11.5 & 11.4 & $10 \cdot 8$ & $17 \cdot 3$ & $19 \cdot 1$ & $17 \cdot 4$ & $17 \cdot 3$ & $10 \|$ \\
\hline Cys & 1.5 & 1.8 & $1 \cdot 2$ & $1 \cdot 1$ & 3.0 & $2 \cdot 8$ & $2 \cdot 8$ & $2 \cdot 6$ & \\
\hline Phe & $14 \cdot 7$ & $16 \cdot 0$ & $15 \cdot 2$ & $14 \cdot 0$ & $21 \cdot 4$ & $26 \cdot 1$ & $22 \cdot 8$ & $22 \cdot 2$ & 189 \\
\hline Tyr & 11.1 & $12 \cdot 1$ & 11.4 & $10 \cdot 8$ & $16 \cdot 9$ & 21.4 & $17 \cdot 3$ & $17 \cdot 7$ & \\
\hline Thr & $15 \cdot 2$ & $16 \cdot 7$ & $15 \cdot 7$ & 14.5 & 23.5 & $27 \cdot 8$ & $23 \cdot 1$ & $23 \cdot 7$ & 8 \\
\hline $\operatorname{Trp}^{\star \star}$ & $3 \cdot 0$ & $3 \cdot 0$ & $3 \cdot 0$ & $3 \cdot 0$ & 4.5 & 4.5 & 4.5 & 4.5 & 2 \\
\hline Val & $16 \cdot 5$ & 17.5 & $16 \cdot 5$ & $15 \cdot 6$ & $24 \cdot 2$ & 29.7 & $24 \cdot 3$ & 24.9 & 12 \\
\hline Asp & 32.4 & $30 \cdot 0$ & $25 \cdot 7$ & $19 \cdot 8$ & $48 \cdot 2$ & $51 \cdot 0$ & $40 \cdot 0$ & $31 \cdot 6$ & - \\
\hline Glu & 69.7 & $67 \cdot 2$ & $61 \cdot 1$ & $47 \cdot 7$ & $100 \cdot 2$ & 108.5 & $87 \cdot 7$ & $72 \cdot 8$ & - \\
\hline Ala & $23 \cdot 3$ & $21 \cdot 2$ & $18 \cdot 2$ & $13 \cdot 4$ & $35 \cdot 6$ & $36 \cdot 3$ & $28 \cdot 3$ & 21.5 & - \\
\hline Gly & 25.4 & $23 \cdot 7$ & 21.4 & $15 \cdot 5$ & 38.5 & 39.5 & $31 \cdot 7$ & $25 \cdot 1$ & - \\
\hline Pro & $22 \cdot 2$ & $22 \cdot 9$ & $18 \cdot 5$ & $19 \cdot 0$ & 31.9 & $36 \cdot 6$ & $26 \cdot 6$ & $22 \cdot 2$ & - \\
\hline Ser & 14.5 & $15 \cdot 4$ & $12 \cdot 8$ & $9 \cdot 2$ & $23 \cdot 0$ & 23.1 & $19 \cdot 3$ & $15 \cdot 2$ & - \\
\hline Total IAA & 203.1 & 268.6 & 242.9 & 278.5 & $145 \cdot 2$ & $163 \cdot 8$ & $169 \cdot 1$ & 179.5 & \\
\hline Total DAA & 277.5 & $295 \cdot 0$ & 233.6 & $188 \cdot 4$ & 187.5 & $180 \cdot 4$ & $157 \cdot 6$ & 124.5 & \\
\hline $100 \times N_{\text {IAA }}: N_{\text {total }}$ & $42 \cdot 3$ & $47 \cdot 7$ & 51.0 & $59 \cdot 6$ & 43.6 & $47 \cdot 6$ & $51 \cdot 8$ & $59 \cdot 0$ & \\
\hline
\end{tabular}

DAA, dispensable amino acid; HP, high-protein diet; IAA, indispensable amino acid; LP, low-protein diet.

$\S$ According to the National Research Council ${ }^{(27)}$.

\|l Methionine + cystine.

I Phenylalanine + tyrosine.

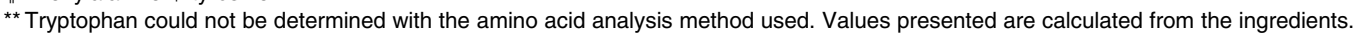




\section{Digestibility trial}

A digestibility trial permitted the assessment of nutrient apparent digestibility for the experimental diets. LP diets were reground and mixed together in proportions so as to obtain a Lys concentration of $26 \mathrm{~g}$ Lys $/ \mathrm{kg}$ DM. The same procedure was carried out with the HP diets in order to obtain one diet with a Lys level of $26 \mathrm{~g}$ Lys/kg DM. Chromic oxide served as the indigestible marker and was added at $10 \mathrm{~g} / \mathrm{kg}$ in both diets. The diets were pelleted using a pellet mill $(5 \mathrm{~mm}$ diameter) and stored at $-20^{\circ} \mathrm{C}$.

Four groups of thirteen rainbow trout, weighing an average of $320 \mathrm{~g}$ per fish, were randomly allocated to four circular tanks with a water temperature of $14.4-15 \cdot 8^{\circ} \mathrm{C}$ and a water flow of $41 / \mathrm{min}$. The two diets (LP and HP) were each dispensed in two randomly chosen tanks. After an adaptation period of $3 \mathrm{~d}$ to the respective experimental diets and a fasting period of $4 d$, the fish were under experiment for $16 \mathrm{~d}$. Faeces were collected continuously with a rotating automatic faeces collector system ${ }^{(30)}$ that ensures minimum contact of the faeces with the water. The exiting water carrying the faeces was filtered directly and continuously. Once a day we collected faeces from the trays and then fed the fish. Feed was collected in a basket for $1 \mathrm{~h}$ after feeding to prevent it from contaminating the faeces produced during that day. All the faeces collected per tank were mixed together, freeze-dried, ground and stored at $-20^{\circ} \mathrm{C}$ until analysis.

\section{Sampling and chemical analysis}

For the dose-response trial, the diets and fish were analysed for DM, crude protein $(\mathrm{N} \times 6.25)$, crude ash and AA content (Tables 1 and 3). Proximate analyses of the samples were conducted as previously reported ${ }^{(31)}$. The same analyses were performed for the diets and faeces of the digestibility trial, as well as the determination of chromium III (trivalent) that involves digestion of organic matter, solubilisation of chromium and determination of chromium by simple photometry ${ }^{(32,33)}$. The crude energy content of the diets and of the faeces was determined with a bomb calorimeter (1241 Oxygen Bomb Calorimeter; Parr Instrument Company, IL, USA).

\section{Calculations}

The initial variables that were obtained or measured directly during and after the experiment were the following: DI is the dry diet intake per fish (g DM/fish) during the experimental period; NI is the $\mathrm{N}$ intake per fish ( $\mathrm{g} \mathrm{N} / \mathrm{fish}$ ); LysI is the Lys intake $(\mathrm{g} / \mathrm{kg}$ MBW per $\mathrm{d})$; $\mathrm{n}$ is the mean number of fish per aquarium, obtained by summing the number of fish per aquarium at the beginning and at the end of the experiment and then dividing by $2 ; \mathrm{W}_{\mathrm{f}}$ and $\mathrm{W}_{\mathrm{i}}$ are the average final and initial fresh body weights $(\mathrm{g})$ per fish; feeding $\mathrm{d}_{\mathrm{d}}$ is the number of feeding days (31 for the present experiment); $\mathrm{N}_{\mathrm{f}}$ and $\mathrm{N}_{\mathrm{i}}$ are the mean $\mathrm{N}$ contents of the whole-body fry at the end and at the beginning of the experimental period ( $\mathrm{g} \mathrm{N} / \mathrm{g}$ ); mean $\mathrm{MBW}$ (in $\mathrm{kg}^{075} / \mathrm{fish}$ ) was calculated as $\left(\left(\mathrm{W}_{\mathrm{f}} / 1000\right)^{0.75}+\left(\mathrm{W}_{\mathrm{i}} / 1000\right)^{0.75}\right) / 2 ; \quad \mathrm{Lys}_{\mathrm{f}}$ and $\mathrm{Lys}_{\mathrm{i}}$ are the Lys contents (in g/g total AA) of the whole-body fish proteins at the end and at the beginning of the experiment, respectively.
The following response criteria were calculated:

Daily growth coefficient $\left(\mathrm{g}^{1 / 3}\right.$ per $\left.\mathrm{d}, \times 1000\right)$

$$
=1000 \times\left(\mathrm{W}_{\mathrm{f}}^{1 / 3}-\mathrm{W}_{\mathrm{i}}^{1 / 3}\right) / \text { feeding }_{\mathrm{d}} .
$$

Feed efficiency $(\mathrm{g} / \mathrm{g}$ DM $)=\left(\mathrm{W}_{\mathrm{f}}-\mathrm{W}_{\mathrm{i}}\right) / \mathrm{DI}$.

Protein productive value (PPV) $(\%)$

$$
=\left(\mathrm{W}_{\mathrm{f}} \times \mathrm{N}_{\mathrm{f}}-\mathrm{W}_{\mathrm{i}} \times \mathrm{N}_{\mathrm{i}}\right) / \mathrm{NI} \text {. }
$$

Feed intake $(\mathrm{gDM} / \mathrm{kg} \mathrm{MBW}$ per $\mathrm{d})=\mathrm{DI} /\left(\mathrm{MBW} \times\right.$ feeding $\left._{\mathrm{d}}\right)$.

Body weight gain (g/kg MBW per d)

$$
=\left(\mathrm{W}_{\mathrm{f}}-\mathrm{W}_{\mathrm{i}}\right) /\left(\mathrm{MBW} \times \text { feeding }_{\mathrm{d}}\right) .
$$

Protein gain $(\mathrm{g} / \mathrm{kg} \mathrm{MBW}$ per $\mathrm{d})=$

$$
6 \cdot 25 \times\left(\mathrm{W}_{\mathrm{f}} \times \mathrm{N}_{\mathrm{f}}-\mathrm{W}_{\mathrm{i}} \times \mathrm{N}_{\mathrm{i}}\right) /\left(\mathrm{MBW} \times \text { feeding }_{\mathrm{d}}\right) .
$$

Protein in weight gain $(\mathrm{g} / \mathrm{kg})=$

$(1000 \times$ protein gain)/body weight gain .

Fat gain $(\mathrm{g} / \mathrm{kg} \mathrm{MBW}$ per $\mathrm{d})=$

$$
\left(\mathrm{W}_{\mathrm{f}} \times \mathrm{LIP}_{\mathrm{f}}-\mathrm{W}_{\mathrm{i}} \times \mathrm{LIP}_{\mathrm{i}}\right) /\left(\mathrm{MBW} \times \text { feeding }_{\mathrm{d}}\right) .
$$

LIP is the lipid content in $\mathrm{g} / \mathrm{g}$ body weight and it was calculated as:

$$
\begin{aligned}
\mathrm{LIP}= & 1-\text { water content }(\mathrm{g} / \mathrm{g} \text { body weight }) \\
& -\operatorname{ash}(\mathrm{g} / \mathrm{g} \text { body weight })-\text { protein content }(\mathrm{gN} \\
& \times 6 \cdot 25 / \mathrm{g} \text { body weight }) .
\end{aligned}
$$

Fat in weight gain $(\mathrm{g} / \mathrm{kg})=$

$(1000 \times$ fat gain $) /$ body weight gain.

$$
\begin{aligned}
& \text { Lys gain (g Lys/kg MBW per d) } \\
& =6.25 \times\left(\mathrm{W}_{\mathrm{f}} \times \mathrm{N}_{\mathrm{f}} \times \mathrm{Lys}_{\mathrm{f}}-\mathrm{W}_{\mathrm{i}} \times \mathrm{N}_{\mathrm{i}} \times \mathrm{Lys}_{\mathrm{i}}\right) /(\mathrm{MBW} \\
& \left.\times \text { feeding }_{d}\right) \text {. }
\end{aligned}
$$

Lys retention efficiency above maintenance $=$ the slope of the linear relationship between Lys gain and Lys intake at marginal dietary Lys concentrations $(\leq 10 \mathrm{~g} / \mathrm{kg} \mathrm{DM})^{(34,35)}$.

$$
\text { Lys retention efficiency }(\%)=100 \times(\text { Lys gain } / \text { LysI }) \text {. }
$$

$\mathrm{E}$ is the Lys maintenance requirement in $\mathrm{g} / \mathrm{kg} \mathrm{MBW}$ per $\mathrm{d}$. It was calculated as the $\mathrm{x}$-intercept of the linear relationship between Lys intake (g Lys/kg MBW per d) and Lys gain 
(g Lys/kg MBW per d).

$$
\begin{aligned}
& \text { Lys efficiency of utilisation }(\%)= \\
& 100 \times((\text { Lys gain }+ \text { E) } / \text { LysI }) .
\end{aligned}
$$

\section{Data analysis}

The linear model used was the BLM of Robbins et al. ${ }^{(23)}$ :

$$
\mathrm{Y}=\mathrm{P}+\mathrm{U} \times(\mathrm{X}-\mathrm{R}) \times \mathrm{Z}+\varepsilon,
$$

where $\mathrm{Y}$ is the response criterion; $\mathrm{P}$ is the plateau value; $\mathrm{R}$ is the requirement; $\mathrm{X}$ is the independent variable (Lys dietary concentration in $\mathrm{g} / \mathrm{kg} \mathrm{DM}$ or Lys intake in $\mathrm{g} / \mathrm{kg} \mathrm{MBW}$ per $\mathrm{d}$ ); $\mathrm{U}$ is the slope of the line; $\mathrm{Z}$ is a categorical variable which equals 1 when $\mathrm{X}<\mathrm{R}$ and equals 0 otherwise; $\varepsilon$ is the error term.

The $\mathrm{x}$-intercept, I, is calculated as $\mathrm{R}-\mathrm{P} / \mathrm{U}$. The Lys efficiency of utilisation was modelled with an inverse BLM which differs from the BLM in that $\mathrm{Z}$ equals 1 when $\mathrm{X}>\mathrm{R}$ and equals 0 otherwise.

The non-linear model used was the SKM- $4^{(24,36,37)}$ :

$$
\mathrm{Y}=\left(\left(\left(\mathrm{b} \times \mathrm{k}^{\mathrm{n}}\right)+\left(\mathrm{y}_{\max } \times \mathrm{X}^{\mathrm{n}}\right)\right) /\left(\mathrm{k}^{\mathrm{n}}+\mathrm{X}^{\mathrm{n}}\right)\right)+\varepsilon,
$$

where $\mathrm{X}$ is the independent variable (Lys intake or Lys dietary concentration); $\mathrm{Y}$ is the response criterion; $\mathrm{b}$ is the intercept on the $\mathrm{y}$-axis (for $\mathrm{x}=0$ ); $\mathrm{k}$ is the concentration for $\mathrm{y}_{\max } / 2$; $\mathrm{n}$ is the apparent kinetic order; $\mathrm{y}_{\max }$ is the maximum response; $\varepsilon$ is the error term.

Three particular intake levels of interest are the intake at maximum slope $\left(\mathrm{X}_{\mathrm{ms}}\right)$, the intake of maximum efficiency $\left(\mathrm{X}_{\mathrm{me}}\right)$, and the intake of zero response (I) which is only possible to calculate if $\mathrm{b}<0^{(36)}$ :

$$
\begin{gathered}
\mathrm{X}_{\mathrm{ms}}=\mathrm{k} \times((\mathrm{n}-1) /(\mathrm{n}+1))^{1 / \mathrm{n}}, \\
\mathrm{X}_{\mathrm{me}}=\mathrm{k} \times(\mathrm{n}-1)^{1 / \mathrm{n}}, \\
\mathrm{I}=\mathrm{k} \times\left(-\mathrm{b} / \mathrm{y}_{\max }\right)^{1 / \mathrm{n}},
\end{gathered}
$$

The Lys requirement was estimated at $0.95 y_{\max }$ and $0 \cdot 90 \mathrm{y}_{\max }^{(38)}$.

Lys retention efficiency was modelled with the polynomial model of Heger \& Frydrych ${ }^{(39)}$ :

$$
\mathrm{Y}=\mathrm{a} \times \mathrm{X}^{-1}+\mathrm{b}+\mathrm{c} \times \mathrm{X}+\mathrm{d} \times \mathrm{X}^{2}+\varepsilon,
$$

where $\mathrm{a}, \mathrm{b}, \mathrm{c}$ and $\mathrm{d}$ are unknown coefficients.

Lys efficiency of utilisation was modelled with a composite model based on the $\operatorname{BLM}^{(23)}$ and the inverse exponential $\operatorname{model}^{(38)}$.

$$
\mathrm{Y}=(\mathrm{a}+\mathrm{b} \times \mathrm{X} \times \exp (-\mathrm{c} \times \mathrm{X})) \times(\mathrm{Z}-1)^{2}+\mathrm{d} \times \mathrm{Z}+\varepsilon,
$$

where $\mathrm{a}, \mathrm{b}, \mathrm{c}$ and $\mathrm{d}$ are unknown coefficients; $\mathrm{Z}$ is a categorical variable applied separately for each Lys dose, it equals 1 when $\mathrm{X}$ is less than the breakpoint and equals 0 otherwise.

The model parameters were estimated by a classical least squares method for linear models and by iterative least squares procedures for non-linear and composite models. Calculations were carried out with the $\mathrm{R}$ statistical software package version 2.5.0 (University of Auckland, Auckland, New Zealand) and JMP statistical software package version
7 (SAS Institute, Cary, NC, USA) ${ }^{(40)}$. The level of significance chosen was $P<0 \cdot 05$. Models involving the two protein levels (HP and LP) were always estimated independently. Model parameters comparison was done with a Student's $t$ test for classical cases and through bootstrap procedures when classical tests were not directly available. This was, for example, the case in the estimation of the difference between the Lys requirement for HP and LP protein levels: a bootstrap procedure $^{(41)}$ on models residuals was applied to build $95 \% \mathrm{CI}$ on this difference.

\section{Results}

\section{Digestibility trial}

The proximate analyses of the experimental LP and HP diets for the digestibility trial $(26 \mathrm{~g} \mathrm{Lys} / \mathrm{kg} \mathrm{DM})$ are found in Table 1. LP and HP diets did not have significantly different apparent digestible coefficient (ADC) values for Lys (mean 99.3 (SE 0.12) \%) or for ash (mean 53.2 (SE 0.68) \%). Because the Lys apparent digestible coefficient value was $99 \%$, the Lys of the LP and HP diets was considered completely absorbed and available for the trout fry in the present experiment. The apparent digestible coefficient values were significantly different for crude protein (98.0 (SE 0.09) \% for LP; 98.7 (SE 0.09) \% for HP), DM (88.4 (SE 0.35$) \%$ for LP; 91.8 (SE 0.35$) \%$ for HP), and crude energy (92.0 (SE 0.32$) \%$ for LP; 94.9 (SE 0.32) \% for HP). Thus, digestible protein and digestible energy contents were of about $310 \mathrm{~g} / \mathrm{kg} \mathrm{DM}$ and $22 \mathrm{MJ} / \mathrm{kg}$ DM for LP diets and $469 \mathrm{~g} / \mathrm{kg} \mathrm{DM}$ and $23 \mathrm{MJ} / \mathrm{kg} \mathrm{DM}$ for HP diets (Table 1). The differences in digestible energy content were considered minor, and the differences in digestible protein content were adequate for the purpose of the experiment.

\section{Dose-response trial}

In the dose-response trial, fry fed LP6 to LP15 diets or HP5 to HP15 diets increased their mean initial body weight $(0.78 \mathrm{~g} /$ fish) by a factor of at least three by the end of the experiment (Table 4), thus showing good growth rates despite high concentrations of crystalline AA in the diets $(66.4 \%$ of crude protein for both LP and HP diets). A high mean mortality of thirteen fish per aquarium (22\%) was observed for the two diets with the lowest Lys concentrations at both protein levels (LP0, LP1, HP0, HP1). For the diets LP2 to LP15 and HP2 to HP15 the average mortality was of only one fish per aquarium $(1.7 \%)$.

Body weight gain, daily growth coefficient, feed efficiency, PPV, DM intake, protein gain and Lys gain (Table 4) were all plotted against the Lys dietary concentration and were fitted with the SKM-4 non-linear model (best fit model, see Table 5 for parameter values for body weight gain, protein gain and Lys gain). The $\mathrm{y}_{\max }$ parameter was found to be significantly different between LP and HP diets for all criteria. For body weight gain, protein gain and Lys gain, the HP diets had a significantly greater $\mathrm{y}_{\max }$ and inversely, for DM intake and PPV, it was the LP diets that had a significantly higher $\mathrm{y}_{\max }$ (results not shown). 


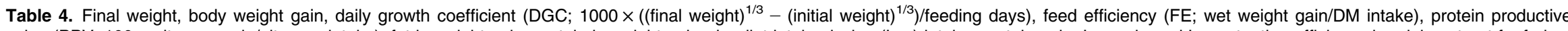
value (PPV; $100 \times$ nitrogen gain/nitrogen intake), fat in weight gain, protein in weight gain, dry diet intake, lysine (Lys) intake, protein gain, Lys gain and Lys retention efficiency in rainbow trout fry fed on graded levels of Lys for $31 \mathrm{~d} \S$

(Values for one group of sixty fry)

\begin{tabular}{|c|c|c|c|c|c|c|c|c|c|c|c|c|c|c|c|c|c|}
\hline Dietary Lys (g/kg DM) & $\begin{array}{l}\text { LP } \\
\text { HP }\end{array}$ & $\begin{array}{l}2 \\
2 \\
0\end{array}$ & $\begin{array}{l}4 \\
6 \\
1\end{array}$ & $\begin{array}{l}6 \\
9 \\
2\end{array}$ & $\begin{array}{c}8 \\
12 \\
3\end{array}$ & $\begin{array}{c}10 \\
15 \\
4\end{array}$ & $\begin{array}{c}12 \\
18 \\
5\end{array}$ & $\begin{array}{c}14 \\
21 \\
6\end{array}$ & $\begin{array}{c}16 \\
24 \\
7\end{array}$ & $\begin{array}{c}18 \\
27 \\
8\end{array}$ & $\begin{array}{c}20 \\
30 \\
9\end{array}$ & $\begin{array}{l}22 \\
33 \\
10\end{array}$ & $\begin{array}{l}24 \\
36 \\
11\end{array}$ & $\begin{array}{l}26 \\
39 \\
12\end{array}$ & $\begin{array}{l}33 \\
50 \\
13\end{array}$ & $\begin{array}{l}40 \\
60 \\
14\end{array}$ & $\begin{array}{l}47 \\
70 \\
15\end{array}$ \\
\hline \multirow[t]{2}{*}{ Final wt (g/fish) } & LP & 0.84 & 1.07 & 1.29 & 1.93 & $2 \cdot 31$ & 3.34 & 3.94 & 4.48 & 4.26 & $4 \cdot 17$ & $4 \cdot 26$ & $4 \cdot 32$ & 4.54 & $4 \cdot 27$ & 4.80 & 4.53 \\
\hline & $\mathrm{HP}$ & 0.89 & 0.91 & 1.62 & 1.90 & $3 \cdot 30$ & $4 \cdot 28$ & $5 \cdot 21$ & $5 \cdot 10$ & $5 \cdot 05$ & 5.03 & 5.89 & $5 \cdot 72$ & $5 \cdot 23$ & 5.44 & $5 \cdot 10$ & $5 \cdot 14$ \\
\hline \multirow[t]{2}{*}{ Body wt gain (g/fish) } & LP & 0.06 & 0.28 & 0.52 & 1.14 & 1.53 & 2.56 & $3 \cdot 17$ & 3.70 & 3.49 & 3.39 & 3.48 & 3.55 & 3.75 & 3.51 & 4.01 & 3.75 \\
\hline & $\mathrm{HP}$ & 0.11 & 0.13 & 0.84 & $1 \cdot 13$ & 2.52 & 3.51 & 4.42 & 4.32 & $4 \cdot 27$ & $4 \cdot 26$ & $5 \cdot 10$ & 4.94 & 4.46 & 4.65 & 4.32 & 4.37 \\
\hline \multirow[t]{2}{*}{$\begin{array}{l}\mathrm{DGC}\left(\mathrm{g}^{1 / 3} \text { per } \mathrm{d}\right. \\
\times 1000)\end{array}$} & LP & 0.68 & $3 \cdot 19$ & 5.51 & $10 \cdot 33$ & 12.96 & 18.58 & 21.37 & 23.46 & $22 \cdot 68$ & $22 \cdot 18$ & $22 \cdot 66$ & 22.92 & $23 \cdot 68$ & $22 \cdot 83$ & 24.62 & $23 \cdot 64$ \\
\hline & $\mathrm{HP}$ & 1.37 & 1.60 & $8 \cdot 19$ & $10 \cdot 36$ & $18 \cdot 35$ & $22 \cdot 78$ & $26 \cdot 08$ & $25 \cdot 81$ & 25.63 & $25 \cdot 73$ & 28.48 & 28.00 & $26 \cdot 49$ & 26.94 & $25 \cdot 77$ & 26.03 \\
\hline \multirow[t]{2}{*}{ FE (g/kg DM) } & LP & 0.12 & 0.26 & 0.52 & 0.78 & 0.85 & 0.96 & 1.07 & 1.08 & 1.07 & 1.05 & 1.09 & $1 \cdot 14$ & $1 \cdot 15$ & 1.09 & 1.08 & $1 \cdot 14$ \\
\hline & $\mathrm{HP}$ & 0.11 & 0.25 & 0.81 & 0.99 & 1.29 & 1.37 & 1.40 & 1.39 & 1.34 & 1.34 & 1.41 & 1.37 & 1.42 & 1.43 & 1.32 & 1.44 \\
\hline \multirow[t]{2}{*}{ PPV (\%) } & LP & $-14 \cdot 70$ & 2.55 & $9 \cdot 38$ & $20 \cdot 89$ & 29.41 & 34.97 & $39 \cdot 20$ & $45 \cdot 38$ & $41 \cdot 72$ & 46.98 & 45.99 & 48.03 & 48.08 & 46.53 & 45.93 & $48 \cdot 67$ \\
\hline & $\mathrm{HP}$ & -5.13 & 1.53 & $15 \cdot 16$ & 19.62 & 31.87 & 36.85 & 39.19 & 40.35 & 39.47 & 41.08 & 41.23 & $40 \cdot 11$ & 42.39 & $42 \cdot 28$ & 41.39 & 43.63 \\
\hline \multirow[t]{2}{*}{ Fat in wt gain $(\mathrm{g} / \mathrm{kg})$} & LP & 347.9 & $221 \cdot 6$ & $215 \cdot 6$ & $206 \cdot 9$ & $172 \cdot 2$ & 183.9 & $183 \cdot 7$ & $169 \cdot 8$ & $178 \cdot 1$ & 153.4 & $160 \cdot 0$ & $170 \cdot 1$ & $170 \cdot 6$ & $168 \cdot 4$ & $166 \cdot 4$ & 167.5 \\
\hline & $\mathrm{HP}$ & 243.5 & 373.6 & $162 \cdot 1$ & 177.5 & $148 \cdot 3$ & $150 \cdot 2$ & $145 \cdot 9$ & 138.0 & 133.8 & 132.9 & $136 \cdot 0$ & 134.8 & 158.5 & $151 \cdot 7$ & $129 \cdot 7$ & $139 \cdot 3$ \\
\hline \multirow[t]{2}{*}{ Protein in wt gain $(\mathrm{g} / \mathrm{kg})$} & LP & $-489 \cdot 3$ & $22 \cdot 0$ & $55 \cdot 1$ & 84.6 & $109 \cdot 3$ & $115 \cdot 6$ & 115.4 & $132 \cdot 3$ & 123.5 & $140 \cdot 7$ & $131 \cdot 3$ & $133 \cdot 3$ & $132 \cdot 0$ & $135 \cdot 0$ & $135 \cdot 0$ & 134.3 \\
\hline & $\mathrm{HP}$ & $-104 \cdot 2$ & 31.5 & 85.5 & 94.5 & $116 \cdot 5$ & $127 \cdot 1$ & 131.9 & 137.0 & 138.4 & $144 \cdot 2$ & $137 \cdot 6$ & $138 \cdot 1$ & 140.9 & $139 \cdot 6$ & $147 \cdot 9$ & 142.4 \\
\hline \multirow{2}{*}{$\begin{array}{l}\text { Dry diet intake (g/kg } \\
\text { MBW per d) }\end{array}$} & LP & 3.90 & $4 \cdot 65$ & $5 \cdot 42$ & $6 \cdot 77$ & 7.65 & $9 \cdot 34$ & $9 \cdot 36$ & 10.01 & 9.89 & 9.82 & 9.53 & 9.35 & 9.50 & 9.75 & $10 \cdot 49$ & 9.53 \\
\hline & HP & $3 \cdot 19$ & 3.76 & 5.09 & 5.42 & 6.84 & 7.75 & 8.44 & 8.45 & 8.67 & 8.72 & 8.98 & $9 \cdot 14$ & 8.45 & 8.50 & 8.88 & 8.18 \\
\hline \multirow{2}{*}{$\begin{array}{l}\text { Lys intake (mg/kg MBW } \\
\text { per d) }\end{array}$} & LP & $6 \cdot 4$ & $17 \cdot 2$ & $31 \cdot 2$ & 52.9 & 75.5 & 111.5 & $130 \cdot 9$ & $160 \cdot 7$ & $179 \cdot 0$ & $197 \cdot 9$ & $211 \cdot 8$ & $227 \cdot 0$ & $250 \cdot 1$ & 323.9 & $420 \cdot 7$ & $447 \cdot 7$ \\
\hline & HP & 7.9 & $20 \cdot 9$ & $44 \cdot 0$ & 63.5 & 101.4 & $138 \cdot 7$ & $177 \cdot 1$ & $203 \cdot 3$ & 235.4 & 263.5 & $299 \cdot 1$ & $332 \cdot 7$ & 333.7 & $423 \cdot 3$ & 533.4 & 575.4 \\
\hline \multirow{2}{*}{$\begin{array}{l}\text { Protein gain ( } \mathrm{g} / \mathrm{kg} \text { MBW } \\
\text { per d) }\end{array}$} & LP & -0.18 & 0.04 & 0.16 & 0.45 & 0.71 & 1.03 & $1 \cdot 16$ & 1.44 & $1 \cdot 30$ & 1.46 & $1 \cdot 38$ & 1.42 & 1.44 & 1.43 & 1.52 & 1.47 \\
\hline & $\mathrm{HP}$ & -0.08 & 0.03 & 0.36 & 0.50 & 1.03 & 1.35 & 1.56 & 1.61 & 1.61 & 1.69 & 1.74 & 1.73 & 1.69 & 1.69 & 1.73 & 1.68 \\
\hline \multirow{2}{*}{$\begin{array}{l}\text { Lys gain (mg/kg MBW } \\
\text { per d) }\end{array}$} & LP & -1.79 & 0.00 & 1.02 & $2 \cdot 88$ & $5 \cdot 21$ & $7 \cdot 72$ & 8.93 & $11 \cdot 34$ & $10 \cdot 18$ & 11.64 & 10.92 & 11.65 & $11 \cdot 14$ & 11.38 & $12 \cdot 68$ & 12.53 \\
\hline & HP & -0.97 & -0.30 & $2 \cdot 24$ & 3.42 & $7 \cdot 60$ & 10.59 & $12 \cdot 25$ & $12 \cdot 86$ & $13 \cdot 27$ & 13.66 & $14 \cdot 20$ & $14 \cdot 28$ & 14.67 & 13.87 & 14.85 & 14.05 \\
\hline \multirow{2}{*}{$\begin{array}{l}\text { Lys retention efficiency } \\
\text { (\%) }\end{array}$} & LP & $-278 \cdot 1$ & -0.1 & $32 \cdot 8$ & $54 \cdot 4$ & $69 \cdot 0$ & $69 \cdot 3$ & $68 \cdot 2$ & 36.9 & 56.9 & $58 \cdot 8$ & 51.6 & $51 \cdot 3$ & 44.5 & $35 \cdot 1$ & $30 \cdot 1$ & $28 \cdot 0$ \\
\hline & $\mathrm{HP}$ & $-123 \cdot 6$ & -14.3 & $50 \cdot 8$ & $53 \cdot 8$ & $75 \cdot 0$ & $76 \cdot 4$ & $69 \cdot 2$ & $63 \cdot 3$ & $56 \cdot 4$ & 28.4 & $23 \cdot 2$ & $42 \cdot 9$ & 44.0 & $32 \cdot 8$ & $27 \cdot 8$ & 24.4 \\
\hline
\end{tabular}

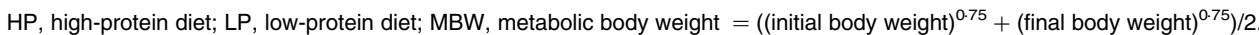

$\S$ For details of procedures and diets, see Materials and methods section and Table 1 . The initial body weight was 0.78 (SD 0.01$) \mathrm{g}$ for the rainbow trout fry and they were kept at a temperature of $14.5-15.5^{\circ} \mathrm{C}$. 
Table 5. Parameters estimated by fitting the non-linear model to the experimental data for the response criteria of body weight gain ( $\mathrm{g} / \mathrm{kg}$ metabolic body weight (MBW) per d), protein gain ( $\mathrm{g} / \mathrm{kg} \mathrm{MBW}$ per d) and lysine (Lys) gain ( $g / k g$ MBW per d)§

\begin{tabular}{|c|c|c|c|c|c|c|c|c|c|c|c|c|}
\hline \multirow[b]{2}{*}{ Lys requirement in terms of... } & \multirow[b]{2}{*}{ Criteria } & \multirow[b]{2}{*}{ Diet } & \multicolumn{4}{|c|}{ Model parameters } & \multirow[b]{2}{*}{$X_{\mathrm{me}}$} & \multirow[b]{2}{*}{$X_{\mathrm{ms}}$} & \multirow[b]{2}{*}{1} & \multirow[b]{2}{*}{ R 0.90} & \multirow[b]{2}{*}{ R 0.95} & \multirow[b]{2}{*}{ RMSE } \\
\hline & & & $\mathrm{B}$ & k & $\mathrm{n}$ & $y_{\max }{ }^{*}$ & & & & & & \\
\hline \multirow[t]{6}{*}{ Dietary DM (g/kg DM) } & \multirow[t]{2}{*}{ Body wt gain } & LP & 0.801 & 8.497 & 3.687 & 11.041 & $11 \cdot 110$ & 7.307 & - & $15 \cdot 073$ & 18.483 & 0.425 \\
\hline & & $\mathrm{HP}$ & 0.798 & 11.982 & 4.129 & $12 \cdot 225$ & 15.795 & $10 \cdot 630$ & - & 20.033 & 24.031 & 0.566 \\
\hline & \multirow[t]{2}{*}{ Protein gain } & LP & -0.100 & $9 \cdot 360$ & 3.594 & 1.491 & $12 \cdot 202$ & 7.983 & 4.418 & 17.600 & 21.646 & 0.066 \\
\hline & & $\mathrm{HP}$ & -0.012 & 13.468 & $4 \cdot 266$ & 1.731 & $17 \cdot 775$ & 12.041 & $4 \cdot 164$ & 22.582 & 26.903 & 0.064 \\
\hline & \multirow{2}{*}{ Lys gain } & LP & -0.012 & $9 \cdot 816$ & 3.327 & 0.123 & $12 \cdot 652$ & $8 \cdot 146$ & 4.864 & 19.592 & 24.489 & 0.006 \\
\hline & & $\mathrm{HP}$ & -0.006 & 14.143 & 4.079 & 0.145 & 18.632 & 12.509 & 6.424 & 24.496 & 29.405 & 0.005 \\
\hline \multirow[t]{6}{*}{ Dietary protein ( $\mathrm{g} / 100 \mathrm{~g}$ protein) } & \multirow[t]{2}{*}{ Body wt gain } & LP & 0.801 & $2 \cdot 815$ & 3.689 & 11.042 & 3.681 & 2.421 & - & 4.993 & $6 \cdot 122$ & 0.425 \\
\hline & & $\mathrm{HP}$ & 0.798 & $2 \cdot 648$ & 4.131 & $12 \cdot 225$ & 3.491 & $2 \cdot 350$ & - & 4.426 & $5 \cdot 308$ & 0.566 \\
\hline & \multirow[t]{2}{*}{ Protein gain } & LP & -0.100 & $3 \cdot 101$ & 3.596 & 1.491 & 4.043 & $2 \cdot 646$ & 1.464 & 5.829 & 7.168 & 0.066 \\
\hline & & $\mathrm{HP}$ & -0.012 & 2.976 & 4.269 & 1.731 & 3.928 & $2 \cdot 661$ & 0.920 & 4.988 & 5.942 & 0.064 \\
\hline & \multirow{2}{*}{ Lys gain } & LP & -0.012 & 3.252 & 3.329 & 0.123 & $4 \cdot 192$ & 2.699 & 1.612 & 6.489 & 8.109 & 0.006 \\
\hline & & $\mathrm{HP}$ & -0.006 & 3.125 & 4.082 & 0.145 & $4 \cdot 118$ & $2 \cdot 765$ & 1.420 & 5.411 & 6.494 & 0.005 \\
\hline \multirow[t]{6}{*}{ Lys intake (g/kg MBW per d) } & \multirow[t]{2}{*}{ Body wt gain } & LP & 0.680 & 0.061 & $2 \cdot 148$ & $11 \cdot 318$ & 0.065 & 0.038 & - & 0.164 & 0.233 & 0.398 \\
\hline & & $\mathrm{HP}$ & 0.651 & 0.069 & 2.514 & $12 \cdot 307$ & 0.082 & 0.050 & - & 0.162 & 0.218 & 0.461 \\
\hline & \multirow[t]{2}{*}{ Protein gain } & LP & -0.107 & 0.072 & $2 \cdot 146$ & 1.547 & 0.077 & 0.045 & 0.021 & 0.209 & 0.295 & 0.067 \\
\hline & & HP & -0.036 & 0.084 & 2.497 & 1.758 & 0.099 & 0.060 & 0.018 & 0.205 & 0.276 & 0.051 \\
\hline & \multirow[t]{2}{*}{ Lys gain } & LP & -0.012 & 0.080 & 1.991 & 0.129 & 0.080 & 0.046 & 0.025 & 0.253 & 0.368 & 0.006 \\
\hline & & $\mathrm{HP}$ & -0.007 & 0.093 & 2.395 & 0.148 & 0.106 & 0.064 & 0.026 & 0.237 & 0.323 & 0.004 \\
\hline
\end{tabular}

b, y-intercept; HP, high-protein diet; l, $x$-intercept and intake of zero response; $k$, concentration for $y_{\max } / 2 ; \mathrm{LP}$, low-protein diet; $\mathrm{n}$, apparent kinetic order; $\mathrm{R} 0.90$, requirement estimated as $0.90 \mathrm{y}_{\max } ; \mathrm{R} 0.95$, requirement estimated as $0.95 y_{\max } ; \mathrm{RMSE}$, root mean square error; $y_{\max }$, the maximum response; $X_{\mathrm{m}}$, intake at maximum slope; $X_{\mathrm{me}}$, intake of maximum efficiency.

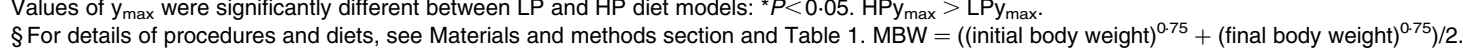


The relative Lys requirement (expressed as g Lys $/ \mathrm{kg} \mathrm{DM}$ ) for all three main response criteria (body weight gain, protein gain and Lys gain) was always greater for the HP diets than for the LP diets (Tables 6 and 7; Fig. 1). However, the significance of this difference (Table 7) depended upon the model used, the response criterion and the definition of the requirement $\left(0.90 y_{\max }\right.$ or $\left.0.95 y_{\max }\right)$ for the SKM-4. For the BLM, the difference of relative Lys requirement between the LP and the HP diets was significant for all three response criteria. On the other hand, for the SKM-4, this difference was not significant for the criteria of protein gain and Lys gain when the $0.95 y_{\max }$ was used. As protein level was increased from LP to HP diets, the relative Lys requirement for optimal Lys gain increased from 16.8 to $23.4 \mathrm{~g} / \mathrm{kg} \mathrm{DM}$, respectively, with the BLM (Table 7). When using $0.90 y_{\max }$ with the SKM-4, the relative Lys requirement increased from 19.6 to $24.5 \mathrm{~g} / \mathrm{kg}$ DM for fish fed the LP and HP diets, respectively (Table 7). When estimating the requirement at $0.95 \mathrm{y}_{\max }$, with the SKM-4, the relative requirement increased from 24.5 to $29.4 \mathrm{~g} / \mathrm{kg}$ DM with increasing protein level (LP and HP diets, respectively). When the relative Lys requirements were expressed in terms of dietary protein (g Lys/100g protein), the difference between the LP and HP requirements was significant only for the SKM-4 using $0 \cdot 90 y_{\max }$ and Lys gain as the response criterion (Table 7).

The Lys requirements were then expressed as an absolute value, that is, as Lys intake $(\mathrm{g} / \mathrm{kg}$ MBW per d) instead of Lys concentration in the diet (Table 7). The absolute Lys requirement for the LP diets was sometimes greater than, sometimes less than and sometimes equal to the requirement for the HP diets. The difference between the absolute LP and HP requirements was only significant in the case of Lys gain with the BLM.

To bring to light the significance effect of the response criterion on the Lys requirement, the criteria may be classified as follows: the Lys requirement for weight gain is definitely smaller than the Lys requirement for protein gain which is smaller than or equal to the requirement for Lys gain (Table 7). For instance, the relative Lys requirements estimated with the BLM were $20.2,22.3$ and $23.4 \mathrm{~g} / \mathrm{kg}$ DM for body weight gain, protein gain and Lys gain, respectively. This progression holds true for the two ways of expressing the Lys requirement, be it relative (as a dietary concentration) or absolute (as an intake).

In addition, the bootstrap procedure was applied on paired residuals for the BLM. For example, the difference in the LP relative requirement for body weight gain and the LP relative requirement for protein gain was calculated and its significance was tested. When this was done for LP and HP diets alike, twelve different tests (or pairs of values) were obtained (Table 8). In nine cases out of twelve the differences were significant which demonstrates clearly that the response criterion most likely has an influence on the value of the relative Lys requirement $(\mathrm{g} / \mathrm{kg} \mathrm{DM})$. The three cases for which the differences were not significant concerned pairs between Lys gain and protein gain.

The BLM and the SKM-4 fit the data about equally well since the $r^{2}$ was of about 0.98-1.00. In all cases for protein and Lys gains, the Lys requirement (in absolute and relative terms) estimated with the BLM was observed to be smaller than the requirement estimated with the non-linear model using $0.90 y_{\max }$, as well as $0.95 y_{\max }$ (Table 7).

All the parameters of the SKM-4 were shown to be necessary. When the parameter $\mathrm{b}$ was removed, the residual standard error increased from 0.043 to 0.056 , demonstrating that it had a role. The bootstrap procedure revealed that the SKM-4 and especially the use of $0 \cdot 95 y_{\max }$ was quite unstable and so the uncertainty associated with its estimation was higher (Table 7). The Lys requirement (in absolute and relative terms) obtained with the SKM-4 using $0 \cdot 90 y_{\max }$ was closer to the requirement obtained with the BLM than the requirement obtained using $0.95 y_{\max }$.

Table 6. Parameters estimated by fitting the broken-line model to the experimental data for the response criteria of body weight gain ( $\mathrm{g} / \mathrm{kg}$ metabolic body weight (MBW) per d), protein gain ( $\mathrm{g} / \mathrm{kg} \mathrm{MBW} \mathrm{per} \mathrm{d)} \mathrm{and} \mathrm{lysine} \mathrm{(Lys)} \mathrm{gain}(\mathrm{g} / \mathrm{kg}$ MBW per d)§

\begin{tabular}{lllllrrr}
\hline Lys requirement in terms of... & Criteria & Diet & R & U & P & I & RMSE \\
\hline Dietary DM (g/kg DM) & Body wt gain & LP & 14.727 & 0.817 & 10.744 & -1.283 & 0.317 \\
& & HP & 20.193 & 0.687 & 11.974 & -1.904 & 0.575 \\
& Protein gain & LP & 16.154 & 0.114 & 1.429 & -0.410 & 0.060 \\
& & HP & 22.329 & 0.095 & 1.686 & -0.437 & 0.079 \\
& Lys gain & LP & 16.798 & 0.009 & 0.115 & -0.036 & 0.007 \\
& & HP & 23.351 & 0.008 & 0.140 & -0.041 & 0.008 \\
Dietary protein (g/100 g protein) & Body wt gain & LP & 4.878 & 2.466 & 10.744 & -1.284 & 0.317 \\
& & HP & 4.462 & 3.111 & 11.974 & -1.907 & 0.575 \\
& Protein gain & LP & 5.351 & 0.344 & 1.429 & -0.410 & 0.060 \\
& & HP & 4.933 & 0.430 & 1.686 & -0.437 & 0.079 \\
& Lys gain & LP & 5.564 & 0.027 & 0.115 & -0.036 & 0.007 \\
& & HP & 5.159 & 0.035 & 0.140 & -0.041 & 0.008 \\
& & LP & 0.135 & 76.283 & 10.744 & 0.058 & 0.373 \\
Lys intake (g/kg MBW per d) & Body wt gain & HP & 0.148 & 80.304 & 11.974 & 0.465 & 0.493 \\
& & LP & 0.150 & 10.664 & 1.429 & -0.168 & 0.061 \\
& Protein gain & HP & 0.165 & 11.205 & 1.674 & -0.171 & 0.058 \\
& & LP & 0.156 & 0.844 & 0.115 & -0.017 & 0.007 \\
& Lys gain & HP & 0.187 & 0.830 & 0.140 & -0.016 & 0.006 \\
\hline
\end{tabular}

HP, high-protein diet; I, x-intercept; LP, low-rotein diet; P, plateau; R, requirement; RMSE, root mean square error; U, slope.

$\S$ For details of procedures and diets, see Materials and methods section and Table 1. MBW $=\left((\text { initial body weight })^{0.75}+(\right.$ final body weight) $\left.)^{0.75}\right) / 2$. 
Table 7. Comparison of the non-linear (NL) and the broken-line (BL) models for the relative lysine (Lys) requirement expressed in terms of diet DM $(\mathrm{g} / \mathrm{kg} \mathrm{DM})$ and in terms of dietary protein $(\mathrm{g} / 100 \mathrm{~g}$ protein), and the absolute Lys requirement expressed in terms of intake $(\mathrm{g} / \mathrm{kg}$ metabolic body weight (MBW) per d) for the response criteria of body weight gain ( $/ \mathrm{kg}$ MBW per d), protein gain $(\mathrm{g} / \mathrm{kg} \mathrm{MBW}$ per d) and Lys gain ( $\mathrm{g} / \mathrm{kg}$ MBW per d)§

\begin{tabular}{|c|c|c|c|c|c|c|c|c|c|}
\hline $\begin{array}{l}\text { Lys requirement } \\
\text { in terms of... }\end{array}$ & $\begin{array}{l}\text { Response } \\
\text { criterion }\end{array}$ & Model & $\mathrm{Rq} \mathrm{HP}$ & $\mathrm{Rq} \mathrm{LP}$ & $\mathrm{Rq} \mathrm{HP}-\mathrm{Rq} \mathrm{LP}$ & $95 \% \mathrm{Cl}^{\prime \prime}$ & $\begin{array}{l}\text { Significance of } \\
\text { the difference }\end{array}$ & $R^{2} \mathrm{HP}$ & $R^{2} \mathrm{LP}$ \\
\hline \multirow[t]{9}{*}{ Dietary DM } & \multirow{3}{*}{ Body wt gain } & NL 0.95 & 24.03 & 18.48 & 5.55 & $1 \cdot 69,8 \cdot 27$ & $\mathrm{~S}$ & 0.98 & 0.99 \\
\hline & & NL 0.90 & $20 \cdot 03$ & $15 \cdot 07$ & 4.96 & $0 \cdot 60,10 \cdot 80$ & $\mathrm{~s}$ & 0.98 & 0.99 \\
\hline & & $\mathrm{BL}$ & $20 \cdot 19$ & 14.73 & 5.47 & $4 \cdot 10,7 \cdot 39$ & $S$ & 0.98 & 0.99 \\
\hline & \multirow[t]{3}{*}{ Protein gain } & NL 0.95 & $26 \cdot 90$ & 21.65 & $5 \cdot 26$ & $-13.41,23.92$ & NS & 0.99 & 0.99 \\
\hline & & NL 0.90 & 22.58 & $17 \cdot 60$ & 4.98 & $-10 \cdot 49,20 \cdot 46$ & NS & 0.99 & 0.99 \\
\hline & & $\mathrm{BL}$ & $22 \cdot 33$ & $16 \cdot 15$ & $6 \cdot 17$ & $4.61,8.04$ & $S$ & 0.99 & 0.99 \\
\hline & \multirow[t]{3}{*}{ Lys gain } & NL 0.95 & 29.41 & 24.49 & 4.92 & $-2 \cdot 38,10 \cdot 41$ & NS & 0.99 & 0.98 \\
\hline & & NL 0.90 & 24.50 & 19.59 & 4.90 & $0.62,8.64$ & $S$ & 0.99 & 0.98 \\
\hline & & $\mathrm{BL}$ & 23.35 & $16 \cdot 80$ & 6.55 & $4.73,9.22$ & $\mathrm{~S}$ & 0.98 & 0.98 \\
\hline \multirow[t]{9}{*}{ Dietary protein } & \multirow[t]{3}{*}{ Body wt gain } & NL 0.95 & $5 \cdot 31$ & $6 \cdot 12$ & -0.81 & $-2.26,0.58$ & NS & 0.98 & 0.99 \\
\hline & & NL 0.90 & 4.43 & 4.99 & -0.57 & $-1.50,0.28$ & NS & 0.98 & 0.99 \\
\hline & & $\mathrm{BL}$ & 4.46 & 4.88 & -0.42 & $-0.78,0.03$ & NS & 0.98 & 0.99 \\
\hline & \multirow[t]{3}{*}{ Protein gain } & NL 0.95 & 5.94 & $7 \cdot 17$ & $-1 \cdot 23$ & $-2 \cdot 88,0.17$ & NS & 0.99 & 0.99 \\
\hline & & NL 0.90 & 4.99 & 5.83 & -0.84 & $-1.82,0.04$ & NS & 0.99 & 0.99 \\
\hline & & $\mathrm{BL}$ & 4.93 & $5 \cdot 35$ & -0.42 & $-0.83,0.05$ & NS & 0.99 & 0.99 \\
\hline & \multirow[t]{3}{*}{ Lys gain } & NL 0.95 & 6.49 & $8 \cdot 11$ & -1.61 & $-3.70,0.07$ & NS & 0.99 & 0.98 \\
\hline & & NL 0.90 & $5 \cdot 41$ & $6 \cdot 49$ & -1.08 & $-2.48,-0.01$ & $S$ & 0.99 & 0.98 \\
\hline & & $\mathrm{BL}$ & $5 \cdot 16$ & $5 \cdot 56$ & -0.41 & $-0.98,0.20$ & NS & 0.98 & 0.98 \\
\hline \multirow[t]{9}{*}{ Lys intake } & \multirow[t]{3}{*}{ Body wt gain } & NL 0.95 & 0.22 & 0.23 & -0.01 & $-0.22,0.20$ & NS & 0.99 & 0.99 \\
\hline & & NL 0.90 & $0 \cdot 16$ & 0.16 & 0.00 & $-0.15,0.15$ & NS & 0.99 & 0.99 \\
\hline & & $\mathrm{BL}$ & 0.15 & 0.13 & 0.01 & $0.00,0.03$ & NS & 0.99 & 0.99 \\
\hline & \multirow[t]{3}{*}{ Protein gain } & NL 0.95 & 0.28 & $0 \cdot 30$ & -0.02 & $-0.24,0.21$ & NS & 0.99 & 0.99 \\
\hline & & NL 0.90 & 0.21 & 0.21 & 0.00 & $-0.16,0.16$ & NS & 0.99 & 0.99 \\
\hline & & $\mathrm{BL}$ & $0 \cdot 16$ & $0 \cdot 15$ & 0.01 & $0.00,0.03$ & NS & 0.99 & 0.99 \\
\hline & \multirow{3}{*}{ Lys gain } & NL 0.95 & 0.32 & 0.37 & -0.045 & $-0.26,0.08$ & NS & 1.00 & 0.98 \\
\hline & & NL 0.90 & 0.24 & 0.25 & -0.017 & $-0.13,0.05$ & NS & 1.00 & 0.98 \\
\hline & & $\mathrm{BL}$ & 0.19 & 0.16 & 0.031 & $0.01,0.05$ & $S$ & 0.99 & 0.98 \\
\hline
\end{tabular}

HP, high-protein diet; LP, low-protein diet; NL 0.90, non-linear model requirement estimated as 0.90ymax; NL 0.95, non-linear model requirement estimated as 0.95y $y_{\text {max }}$ Rq, lysine requirement; $\mathrm{S}$, significant.

$\S$ For details of procedures and diets, see Materials and methods section and Table $1 . \mathrm{MBW}=\left((\text { initial body weight })^{0.75}+(\text { final body weight })^{0.75}\right) / 2$.

\|For the difference between the HP and LP requirement estimates.

The Lys maintenance requirement was estimated from the diets containing suboptimal concentrations of Lys (LP0 to LP6 or $<14 \mathrm{~g} \mathrm{Lys/kg} \mathrm{DM} \mathrm{and} \mathrm{HP0} \mathrm{to} \mathrm{HP5} \mathrm{or}<18 \mathrm{~g}$ Lys/ kg DM). Lys gain (Y; g/kg MBW per d) (Table 4) was plotted against Lys intake $(\mathrm{X} ; \mathrm{g} / \mathrm{kg} \mathrm{MBW}$ per $\mathrm{d})$ and a linear model was fitted (Fig. 2). Because the X-intercepts $(P=0 \cdot 4)$ and slopes $(P=0 \cdot 2)$ of these lines were not significantly different, a single line estimation was made $(\mathrm{Y}=0.88$ (SE 0.02$)$ $\mathrm{X}-0.018$ (SE 0.002), $n$ 13, $r^{2}$ 0.99). The $\mathrm{x}$-intercept was 0.0208 (SE 0.002) g Lys intake/kg MBW per $\mathrm{d}$ and thus gave an estimate for the Lys maintenance requirement.

The Lys retention efficiency was modelled with the polynomial model of Heger \& Frydrych ${ }^{(39)}$ (Fig. 3). For the LP and HP diets, the curves rose sharply, reached a maximum at 70 and $73 \%$ of Lys retention efficiency that corresponded to an intake of 94 and $109 \mathrm{mg} \mathrm{Lys} / \mathrm{kg} \mathrm{MBW}$ per d, for LP and HP diets, respectively. The Lys intakes at optimal protein gain (where the requirement is located at $0.95 \mathrm{y}_{\max }$ ) were of 0.295 and $0.275 \mathrm{mg}$ Lys $/ \mathrm{kg} \mathrm{MBW}$ per $\mathrm{d}$ for LP and HP diets, respectively. Thus, the Lys intake needed to achieve maximum efficiency was situated at 32 and $40 \%$, for LP and HP diets, respectively, of the intake needed to obtain optimal protein gain (Tables 4 and 5).

The efficiency of utilisation of both LP and HP diets was modelled with a composite model based on the BLM and the inverse exponential model (Fig. 4). The models began with very similar plateau values of 96 and $94 \%$ for LP and
HP diets, respectively, up to the break-off point at $0 \cdot 10$ and $0 \cdot 14 \mathrm{~g} / \mathrm{kg}$ MBW per $\mathrm{d}$ of Lys intake. Both inverse exponential curves decreased at very similar rates and remained parallel. The HP diets stayed above the LP diets.

The changes in fat gain (Table 4) followed a similar pattern for LP and HP diets, as did changes in protein gain (Table 4). The fat in weight gain started out at about $250-300 \mathrm{~g} / \mathrm{kg}$ and then quickly levelled off to a plateau above a Lys dietary concentration of $5.7 \mathrm{~g} / \mathrm{kg}$ DM. The plateaus were significantly different from one another $(P<0.0001)$ and were at 176 (SE 4) and 146 (SE 4) g/kg for LP and HP diets, respectively. The protein in weight gain values started out negative and rose to a plateau value for Lys concentrations above $11.7 \mathrm{~g} / \mathrm{kg} \mathrm{DM}$. The plateaus were not significantly different from one another $(P=0.4)$ and were at $130(\mathrm{SE} \mathrm{4})$ and 134 (SE 3) g/kg for LP and HP diets, respectively.

The $\mathrm{N}$ body composition (Table 9) showed no difference between LP- and HP-fed fry $(P=0 \cdot 2)$. For both protein levels, the $\mathrm{N}$ body concentration increased with increasing Lys concentration in the diet $(P=0.002)$. The AA composition of the whole-body protein was significantly different between LP and HP diets for histidine and cystine (Table 9). For both LP and HP diets, histidine increased significantly and arginine decreased significantly, with increasing dietary Lys level. Lys whole-body protein composition increased significantly with increasing dietary Lys level for HP diets though it did not vary significantly for LP diets. 

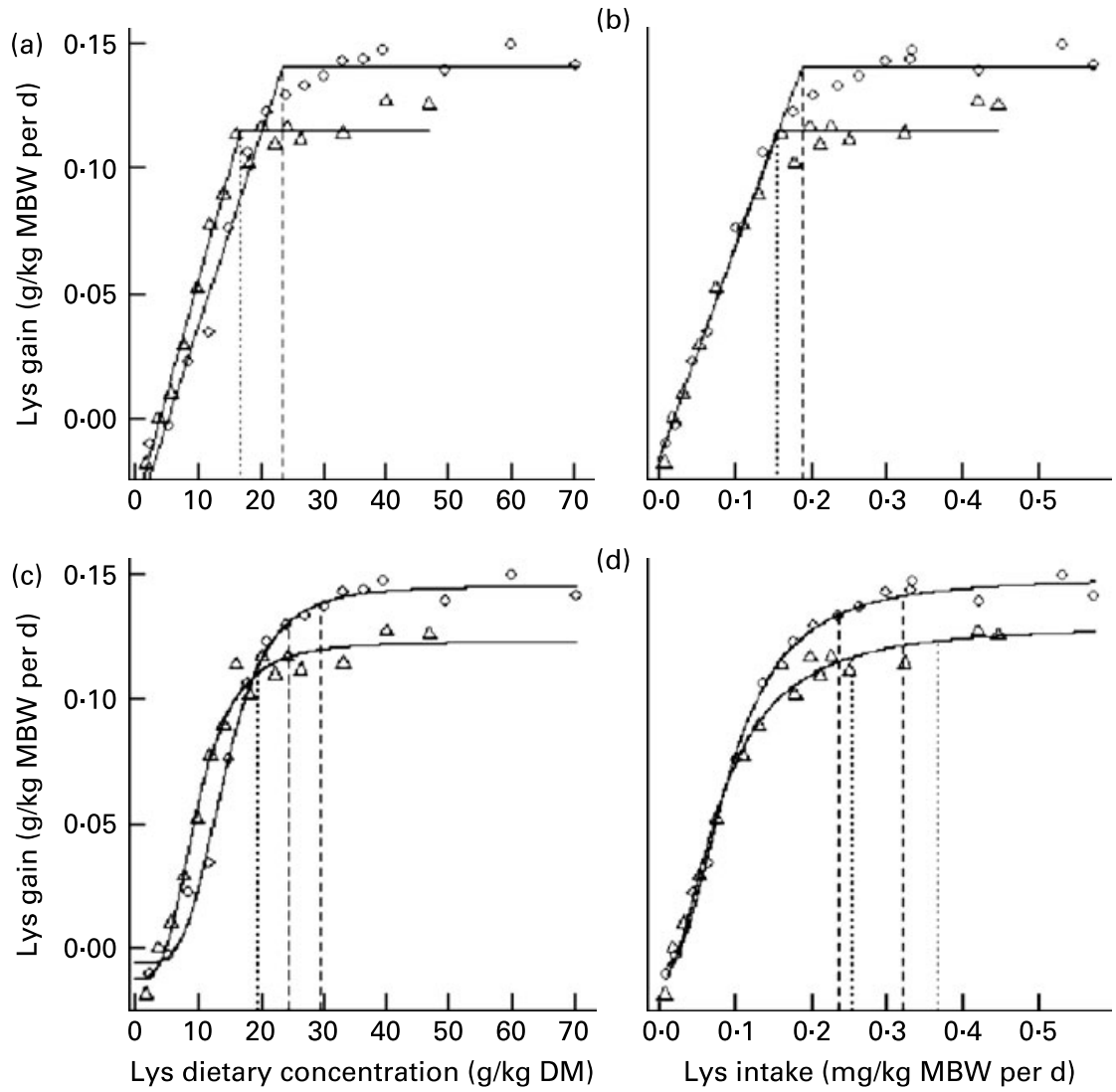

Fig. 1. The lysine (Lys) requirement for Lys gain expressed in $\mathrm{g}$ Lys/kg diet DM (a, c) and in $\mathrm{g}$ Lys intake/kg metabolic body weight (MBW) per $d(b, d)$ estimated with a broken-line model $(a, b)$ or a non-linear saturation kinetics model (SKM-4) (c, d) for low-protein (LP; $\Delta$ ) and high-protein (HP; O) diets. Each point represents one group of sixty fish (rainbow trout, 31 feeding d, initial body weight $0.78 \mathrm{~g} /$ fish). The vertical dotted lines represent the requirement. For the SKM- 4 models, two small dotted lines (…) represent the requirement at $0.90 y_{\max }$ and $0.95 y_{\max }$, from left to right, for the LP diets. The two larger dotted lines (--) represent the requirement at $0.90 y_{\max }$ and $0.95 y_{\max }$, from left to right, for the HP diets. See Tables 5 and 6 for parameter values. MBW $=\left(\left(\right.\right.$ initial body weight) ${ }^{0.75}+$ (final body weight) $\left.{ }^{0.75}\right) / 2$.

To estimate the amount of Lys required to deposit $1 \mathrm{~g}$ body protein, the slope of the linear regression of protein gain $(\mathrm{Y} ; \mathrm{g} /$ $\mathrm{kg}$ MBW per d) (Table 4) against Lys intake (X; g/kg MBW per d) for the Lys-deficient diets $(<14 \mathrm{~g} \mathrm{Lys} / \mathrm{kg}$ DM for LP0 to LP6 and $<18 \mathrm{~g}$ Lys $/ \mathrm{kg}$ DM for HP0 to HP5) was calculated. The inverse value of the slopes $(\times 1000)$ of these linear relationships $(\mathrm{Y}=-0.17(\mathrm{SE} 0.04)+10.64$ (SE 0.5)
$\mathrm{X}, r^{2} 0.99, n 7$ and $\mathrm{Y}=-0.17(\mathrm{SE} 0.03)+11.24(\mathrm{SE} 0.4) \mathrm{X}$, $r^{2} 0.99, n 6$, for LP and HP diets, respectively) indicated that fry fed LP and HP diets required an intake of 94 (SE 4.4) and 89 (SE 3.2) $\mathrm{mg}$ Lys, respectively, to deposit $1 \mathrm{~g}$ body protein. Neither the $\mathrm{x}$-intercepts $(P=0.4)$ nor the slopes $(P=0.2)$ of these linear relationships were significantly different and a single line estimation $(\mathrm{Y}=-0 \cdot 17$

Table 8. The $95 \% \mathrm{Cl}$ for the differences between the relative lysine (Lys) requirements expressed in terms of diet DM ( $\mathrm{g} / \mathrm{kg} \mathrm{DM})$ and between the absolute Lys requirements expressed in terms of intake $(\mathrm{g} / \mathrm{kg}$ metabolic body weight (MBW) per d) for the response criteria of body weight gain ( $/ \mathrm{kg} \mathrm{MBW}$ per d), protein gain ( $\mathrm{g} / \mathrm{kg}$ MBW per d) and Lys gain ( $\mathrm{g} / \mathrm{kg}$ MBW per d) obtained with the broken-line model§

\begin{tabular}{|c|c|c|c|}
\hline \multirow{2}{*}{ Lys requirement in terms of... } & \multirow{2}{*}{ Response criteria } & \multicolumn{2}{|c|}{$95 \% \mathrm{Cl}$} \\
\hline & & LP & HP \\
\hline Dietary DM & $\begin{array}{l}\text { Body wt gain and protein gain } \\
\text { Body wt gain and Lys gain } \\
\text { Protein gain and Lys gain }\end{array}$ & $\begin{array}{l}-2.312,-0.642 \\
-3.298,-0.823 \\
-1.364,0.199\end{array}$ & $\begin{array}{l}-3.404,-0.794 \\
-5.006,-1.166 \\
-1.889,0.277\end{array}$ \\
\hline Lys intake & $\begin{array}{l}\text { Body wt gain and protein gain } \\
\text { Body wt gain and Lys gain } \\
\text { Protein gain and Lys gain }\end{array}$ & $\begin{array}{l}-0.024,-0.005 \\
-0.033,-0.005 \\
-0.015,0.005\end{array}$ & $\begin{array}{l}-0.031,-0.004 \\
-0.058,-0.021 \\
-0.034,-0.010\end{array}$ \\
\hline
\end{tabular}

HP, high-protein diet; LP, low-protein diet.

$\S$ For details of procedures and diets, see Materials and methods section and Table $1 . \mathrm{MBW}=\left((\text { initial body weight })^{0.75}+\right.$ (final body weight $\left.)^{0.75}\right) / 2$. Differences are considered significant when 0 is not contained in the interval of the two values. 
Fig. 2. The lysine (Lys) maintenance requirement estimated by linear regression of Lys gain against Lys intake for the suboptimal low-protein diets LPO to LP6 $\left(\mathrm{O} ; \mathrm{Y}=0.84\right.$ (SE 0.04) $\mathrm{X}-0.017$ (SE 0.003), $n 7, r^{2}$ 0.99, $\mathrm{x}$-intercept $=0.020$ (SE 0.0026) g Lys intake/kg metabolic body weight (MBW) per d) and high-protein diets HP0 to HP5 (- Y $=0.91$ (SE 0.03) X - 0.019 (SE 0.002), $n 6, r^{2} 0.99, x$-intercept $=0.021$ (SE 0.0020) g Lys intake/kg MBW per d). Each symbol represents one group of sixty rainbow trout fry (31 feeding d, initial body weight $0.78 \mathrm{~g} /$ fish). Neither the slopes $(P=0.2)$ nor the $\mathrm{x}$-intercepts $(P=0.4)$ were significantly different. MBW $=\left((\text { initial body weight })^{0.75}+(\text { final body weight })^{0.75}\right) / 2$.

$(\mathrm{SE} 0 \cdot 03)+10.94(\operatorname{SE} 0 \cdot 3) \mathrm{X}, r^{2} 0.99, n$ 13) gave a requirement estimate of 92 (SE 2.5$) \mathrm{mg}$ Lys/g body protein accretion.

\section{Discussion}

The present study tested the effect of dietary protein level on the relative $(\mathrm{g} / \mathrm{kg}$ DM or $\mathrm{g} / 100 \mathrm{~g}$ protein) and absolute (g Lys intake/kg MBW per d) Lys requirements. The relative Lys requirement of trout fry markedly increased $(+5.4 \mathrm{~g} / \mathrm{kg} \mathrm{DM})$ when the digestible protein content increased from 310 to $469 \mathrm{~g} / \mathrm{kg}$ DM (Table 7); therefore, we observed an increase in the relative Lys requirement of about $0.034 \%$ for each $1 \%$ increase in the protein level between 31 and $46.9 \%$ protein. The relative Lys requirement difference was marginally influenced by the model or the response parameter selected for its estimation. Studies with warm-blooded animals also reported an increase of the relative Lys requirement $(\mathrm{g} / \mathrm{kg}$ DM) with increasing dietary protein level ${ }^{(12-14,20)}$. McWard et al. ${ }^{(13)}$ working between 12.8 and $21.7 \%$ protein in swine concluded that the relative Lys requirement $(\mathrm{g} / \mathrm{kg} \mathrm{DM})$ increased by $0.023 \%$ for each $1 \%$ increase in dietary protein. Baker et al. ${ }^{(14)}$ showed an increase in the relative Lys requirement $(\mathrm{g} / \mathrm{kg} \mathrm{DM})$ of growing pigs of $0.02 \%$ for each $1 \%$ increase in dietary protein when working between 12 and $16 \%$ dietary protein. The present results showed an even greater dependence in trout than in pigs between the relative Lys requirement $(\mathrm{g} / \mathrm{kg} \mathrm{DM})$ and the protein level in the diet. This dependence is economically important and should not

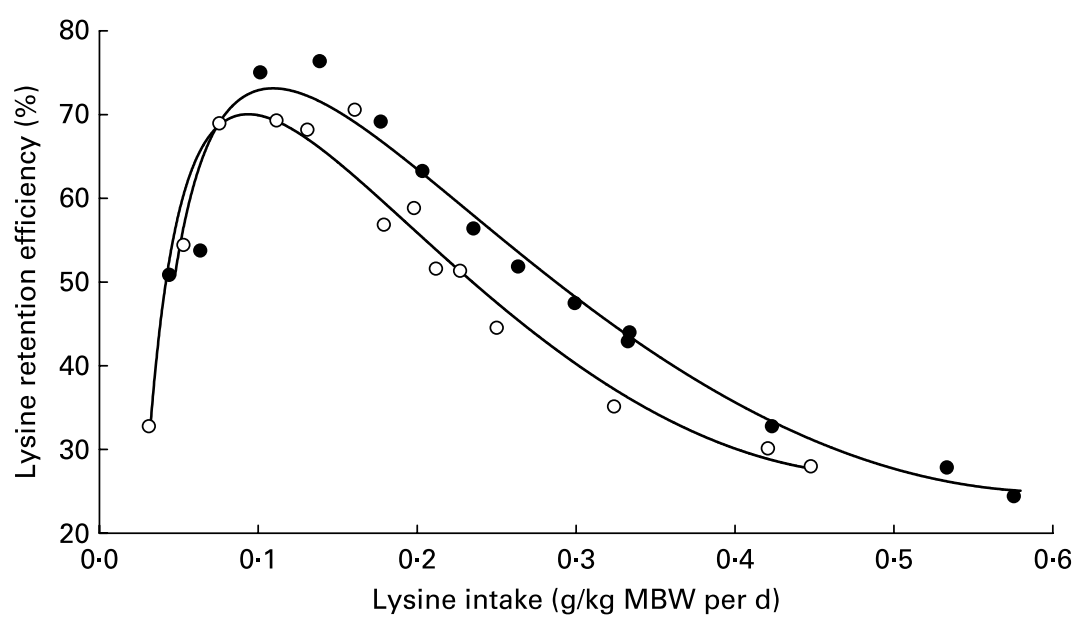

Fig. 3. Lysine (Lys) retention efficiency represented as Lys gain plotted against Lys intake (each symbol represents one group of sixty rainbow trout fry) and modelled with a polynomial model for low-protein (LP; O) and high-protein (HP; $\bullet$ ) diets (LP model: $\mathrm{Y}=-2 \cdot 89 \mathrm{x}^{-1}+135+-404 \mathrm{x}+399 \mathrm{x}^{2}+\varepsilon$, root mean square error $(\mathrm{RMSE})=3.73$ ) (HP model: $Y=-3 \cdot 49 \mathrm{x}^{-1}+141+-355 \mathrm{x}+287 \mathrm{x}^{2}+\varepsilon$, RMSE $\left.=4 \cdot 15\right)$. The diets LP0, LP1, HP0, HP1 were excluded from the model calculations because their retention efficiencies were negative (see Table 4). Metabolic body weight $(\mathrm{MBW})=\left(\left(\right.\right.$ initial body weight) ${ }^{0.75}+\left(\right.$ final body weight) $\left.{ }^{0.75}\right) / 2$. 


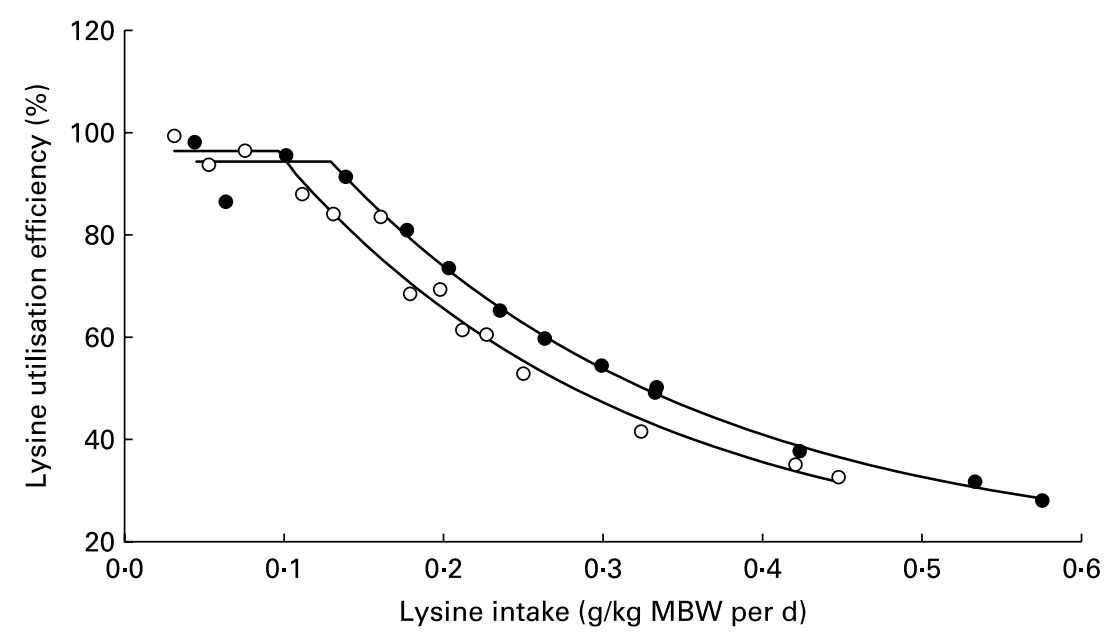

Fig. 4. Plots for lysine (Lys) efficiency of utilisation (\%) calculated as $100 \times($ Lys gain $(\mathrm{g} / \mathrm{kg}$ metabolic body weight (MBW) per d) + Lys maintenance $(0.0208 \mathrm{~g} / \mathrm{kg}$ MBW per d)) divided by Lys intake (g/kg MBW per d). The efficiency of utilisation of both low-protein (LP; O) and high-protein (HP; $\bullet$ ) diets was modelled with a composite model based on the broken-line and the inverse exponential model (LP model: $Y=[15.4+124.7 X \exp (-4.55 X)](Z-1)^{2}+95.3 Z+\varepsilon$, root mean square error $(\mathrm{RMSE})=3.41)\left(\mathrm{HP}\right.$ model: $\left.\mathrm{Y}=[17.7+135.5 \mathrm{X} \exp (-4.41 \mathrm{X})](\mathrm{Z}-1)^{2}+92.4 \mathrm{Z}+\varepsilon, \mathrm{RMSE}=2 \cdot 81\right)$. Each symbol represents one group of sixty rainbow trout fry except for the first point for the LP and HP diets. It is the mean value for LPO and LP1 or HPO and HP1 diets. MBW $=\left((\text { initial body weight })^{0.75}+\right.$ (final body weight) $\left.)^{0.75}\right) / 2$.

be ignored when formulating diets using crystalline Lys to replace part of the dietary protein. Hence, less total dietary Lys is needed in a Lys-supplemented LP diet than in an unsupplemented HP diet. It must be pointed out that the higher amount of digestible carbohydrates in the LP diets compared to the HP diets may have somewhat affected the present Lys requirement results. Indeed, salmonids have a limited capacity to metabolise glucose, though rainbow trout have a higher capacity to digest and absorb starches compared to Atlantic salmon $^{(42,43)}$. In rainbow trout, insulin-specific receptors were found ${ }^{(44,45)}$ though their abundance was lower than in mammals ${ }^{(46)}$. The excessive available carbohydrates may induce metabolic disturbances such as hyperglycaemia ${ }^{(47)}$, glucosuria $^{(48)}$ or impaired liver function ${ }^{(49-51)}$. This may have influenced, in turn, the response variables used to estimate the Lys requirement. However, we believe this influence to be negligible in the present work for the following reasons: (1) LP-fed fish showed a higher voluntary feed intake and a higher PPV than the HP-fed fish, not indicating any metabolic disturbance; (2) the level of available carbohydrates is high in our LP diets but not excessive as dextrin digestibility reported in the literature is low in rainbow trout fry $(44 \%)^{(52)}$ and the maximum recommended available carbohydrate level is $20 \%$ for salmonids ${ }^{(47)}$; (3) this level of available carbohydrates has already been used before for similar LP diets in salmonids ${ }^{(53)}$.

The dietary protein level did not significantly affect the relative Lys requirement for Lys gain when expressed in terms of dietary protein. This confirms the relationship between the relative Lys requirement on an as-fed basis and the dietary protein level. In absolute terms (g Lys intake $/ \mathrm{kg}$ MBW per d) the Lys requirements at $310 \mathrm{~g}$ protein $/ \mathrm{kg}$ DM and at $469 \mathrm{~g}$ protein $/ \mathrm{kg} \mathrm{DM}$ were not significantly different. With the SKM-4 using $0.90 y_{\max }$, for example, the Lys requirement for Lys gain was estimated to be $210 \mathrm{mg}$ Lys intake $/ \mathrm{kg}$ MBW per $d$ for the LP and the HP diets alike. This optimum amount of absolute Lys intake corresponds to the LP9 and HP7 (197.9 and $203.3 \mathrm{mg}$ Lys intake/kg MBW per d, respectively) diets. However, in terms of dietary DM consumption, the fry fed the LP9 diet ate more $(+16 \%)$ than the HP7-fed fry. In conclusion, to achieve the same absolute Lys intake $(\mathrm{g} / \mathrm{kg}$ MBW per d) as the HP-fed fry, the LP fry had a greater voluntary feed intake. This is the primary reason why the Lys requirement when expressed in relative terms $(\mathrm{g} / \mathrm{kg} \mathrm{DM})$ is lower for LP diets. Similar results were reported in work with pigs ${ }^{(14,20,54)}$ and rats ${ }^{(55,56)}$. Our interpretation of the data is further supported by the fact that the effect of the protein level on the Lys requirement virtually disappears when the requirement of Lys is expressed in absolute terms (g Lys intake/kg MBW per d) (Table 7), and the only exception is for Lys gain when the BLM is selected to interpret the present data. The latter observation is probably related to the occurrence of a second or third limiting AA in the LP diet, possibly methionine or histidine (Table 3), that may limit the response of the animals to Lys supplementation or lead to an underestimation of the Lys requirement. Alternatively, it could be related to the inadequacy of the BLM to evaluate the Lys requirement for the HP diets of the present study.

Calculating the percentage of difference between two requirement values $(100 \times$ (greatest value - smallest value)/smallest value) can sum up the effect of a factor on the Lys requirement estimation. Hauler \& $\mathrm{Carter}^{(2)}$ found that the Lys requirements for rainbow trout expressed as a dietary concentration have an order of difference of $121 \%$ which is typical of intra-species variation ${ }^{(57)}$. Hauler \& Carter $^{(2)}$ uphold that the wide variation of Lys requirements in the piscine literature cannot be explained by differences of protein level in the diets. In the present work, the effect of the protein level on the Lys requirement estimation can be assessed by comparing the two protein levels (LP - HP) for all response criteria (liveweight gain, protein gain and Lys gain), all models (BLM, SKM-4(0.90), SKM-4(0.95)) and all modes of expression (Lys concentration and Lys intake). Because the percentage of difference ranged from 1 to $39 \%$, we believe that protein level differences between 
Table 9. Amino acid (AA) composition of whole-body protein ( $g / 100 \mathrm{~g} \mathrm{AA}$ ) and nitrogen whole-body composition ( $\mathrm{g} / 100 \mathrm{~g}$ liveweight) in rainbow trout fry fed on different experimental diets containing graded levels of lysine (Lys) for $31 \mathrm{~d}$

(Values for one group of sixty fry)§

\begin{tabular}{|c|c|c|c|c|c|c|c|c|c|c|c|c|c|c|c|c|c|c|c|}
\hline & \multicolumn{2}{|c|}{ Initial samples } & & \multicolumn{16}{|c|}{ LP and HP diets } \\
\hline & Mean & SE & & 0 & 1 & 2 & 3 & 4 & 5 & 6 & 7 & 8 & 9 & 10 & 11 & 12 & 13 & 14 & 15 \\
\hline \multirow[t]{2}{*}{$\mathrm{N}$} & 1.95 & 0.05 & $\mathrm{LP}^{*}$ & $1 \cdot 31$ & 1.53 & 1.52 & 1.60 & 1.82 & 1.87 & 1.87 & 2.09 & 1.97 & $2 \cdot 19$ & $2 \cdot 07$ & $2 \cdot 10$ & $2 \cdot 08$ & $2 \cdot 12$ & $2 \cdot 13$ & $2 \cdot 11$ \\
\hline & & & $\mathrm{HP}^{*}$ & 1.49 & 1.74 & 1.65 & 1.69 & 1.88 & 2.02 & 2.09 & $2 \cdot 15$ & $2 \cdot 17$ & $2 \cdot 25$ & $2 \cdot 17$ & $2 \cdot 17$ & $2 \cdot 21$ & $2 \cdot 19$ & $2 \cdot 30$ & $2 \cdot 23$ \\
\hline \multicolumn{20}{|l|}{ AA } \\
\hline \multirow[t]{2}{*}{ Arg } & 6.98 & 0.17 & LP† & 6.93 & 6.97 & $6 \cdot 83$ & $7 \cdot 13$ & 7.02 & 7.00 & $6 \cdot 79$ & 6.92 & $6 \cdot 91$ & 6.99 & 6.65 & $6 \cdot 80$ & 6.54 & 6.92 & 6.74 & 6.76 \\
\hline & & & HPt & 7.34 & 6.97 & $6 \cdot 88$ & $6 \cdot 89$ & $6 \cdot 81$ & 6.95 & 7.01 & $6 \cdot 88$ & 7.05 & $6 \cdot 86$ & $6 \cdot 85$ & $6 \cdot 89$ & 7.01 & $6 \cdot 64$ & $6 \cdot 83$ & $6 \cdot 70$ \\
\hline \multirow[t]{2}{*}{ Hisł } & 2.56 & 0.05 & $\mathrm{LP}^{*}$ & $2 \cdot 37$ & $2 \cdot 33$ & 2.45 & $2 \cdot 16$ & 2.46 & $2 \cdot 25$ & 2.54 & 2.44 & $2 \cdot 41$ & $2 \cdot 40$ & 2.48 & $2 \cdot 31$ & $2 \cdot 37$ & 2.45 & 2.53 & $2 \cdot 76$ \\
\hline & & & $\mathrm{HP}^{*}$ & 2.46 & 2.35 & $2 \cdot 27$ & $2 \cdot 28$ & $2 \cdot 19$ & 2.59 & 2.49 & 2.75 & $2 \cdot 87$ & $2 \cdot 56$ & $2 \cdot 58$ & $2 \cdot 63$ & 3.04 & 2.59 & 2.95 & $2 \cdot 71$ \\
\hline \multirow[t]{2}{*}{ Ile } & $4 \cdot 30$ & 0.13 & $\mathrm{LP}^{*}$ & $4 \cdot 11$ & 4.01 & 3.97 & 4.04 & 4.22 & $4 \cdot 12$ & 4.09 & $4 \cdot 12$ & 4.29 & 3.95 & $4 \cdot 37$ & $4 \cdot 36$ & $4 \cdot 19$ & $4 \cdot 20$ & 4.23 & 4.26 \\
\hline & & & HP & $4 \cdot 34$ & 4.09 & 3.83 & $4 \cdot 18$ & 3.63 & $4 \cdot 26$ & $4 \cdot 20$ & $4 \cdot 10$ & $4 \cdot 16$ & $4 \cdot 17$ & $4 \cdot 18$ & 4.06 & $4 \cdot 13$ & $4 \cdot 20$ & 4.45 & $4 \cdot 13$ \\
\hline \multirow[t]{2}{*}{ Leu } & $7 \cdot 70$ & 0.15 & $\mathrm{LP}^{\star}$ & 7.57 & 7.52 & 7.58 & 7.52 & 7.46 & $7 \cdot 31$ & 7.57 & 7.56 & 7.66 & 7.52 & 7.62 & $7 \cdot 71$ & 7.63 & 7.50 & 7.60 & 7.82 \\
\hline & & & $\mathrm{HP}$ & 7.65 & 7.52 & 7.40 & 7.66 & 7.42 & 7.64 & $7 \cdot 61$ & 7.54 & 7.44 & 7.61 & 7.63 & 7.68 & 7.79 & 7.64 & 7.82 & 7.65 \\
\hline \multirow{2}{*}{ Lys } & 8.77 & $0 \cdot 10$ & LP & 8.33 & 8.23 & 8.21 & $7 \cdot 61$ & 7.85 & $7 \cdot 80$ & 7.92 & 8.04 & 7.98 & $8 \cdot 12$ & 8.04 & 8.31 & 7.89 & 8.08 & 8.39 & 8.58 \\
\hline & & & $\mathrm{HP}^{*}$ & 8.22 & 7.93 & 7.64 & 7.73 & 7.73 & 8.03 & 7.98 & $8 \cdot 11$ & $8 \cdot 30$ & $8 \cdot 18$ & 8.22 & $8 \cdot 32$ & 8.70 & 8.26 & 8.60 & 8.41 \\
\hline \multirow[t]{2}{*}{ Met } & 3.33 & 0.05 & LP & 3.28 & 3.42 & $3 \cdot 26$ & 2.85 & $2 \cdot 89$ & $2 \cdot 91$ & $2 \cdot 82$ & 3.00 & $2 \cdot 91$ & 3.04 & $2 \cdot 85$ & 3.05 & $2 \cdot 88$ & 2.90 & 2.85 & 2.94 \\
\hline & & & $\mathrm{HP}$ & 3.26 & 3.02 & 2.96 & 2.88 & 2.73 & 2.94 & $2 \cdot 88$ & 2.87 & $3 \cdot 13$ & 2.97 & 2.96 & 2.96 & 3.01 & 2.91 & $3 \cdot 10$ & 2.94 \\
\hline \multirow[t]{2}{*}{ Cysł } & 0.40 & 0.03 & LP & 0.51 & 0.46 & 0.43 & 0.70 & 0.59 & 0.53 & 0.72 & 0.63 & 0.63 & 0.73 & 0.61 & 0.64 & 0.63 & 0.59 & 0.64 & 0.67 \\
\hline & & & HP & 0.44 & 0.60 & 0.78 & 0.80 & 0.78 & 0.71 & 0.70 & 0.70 & 0.55 & 0.67 & 0.68 & 0.77 & 0.73 & 0.75 & 0.67 & 0.79 \\
\hline \multirow[t]{2}{*}{ Phe } & 4.25 & 0.03 & LP & 4.05 & 4.25 & $4 \cdot 12$ & 4.08 & 4.03 & 4.02 & 4.09 & 4.09 & $4 \cdot 14$ & 4.06 & $4 \cdot 12$ & $4 \cdot 31$ & 4.00 & 4.20 & $4 \cdot 13$ & $4 \cdot 16$ \\
\hline & & & $\mathrm{HP}^{\star}$ & 4.07 & 4.07 & 3.97 & 4.07 & 3.93 & $4 \cdot 10$ & 4.05 & 4.03 & 4.09 & 4.13 & 4.13 & $4 \cdot 19$ & 4.32 & $4 \cdot 26$ & $4 \cdot 19$ & $4 \cdot 10$ \\
\hline \multirow[t]{2}{*}{ Tyr } & 3.51 & 0.00 & LP & 3.43 & 3.36 & 3.51 & 3.06 & 3.08 & 3.00 & 3.09 & $3 \cdot 12$ & 3.23 & $3 \cdot 16$ & $3 \cdot 15$ & 3.26 & 3.05 & $3 \cdot 13$ & $3 \cdot 12$ & $3 \cdot 17$ \\
\hline & & & $\mathrm{HP}$ & 3.51 & $3 \cdot 12$ & $2 \cdot 88$ & 2.83 & 2.79 & $2 \cdot 76$ & $2 \cdot 82$ & 2.69 & 3.38 & 3.13 & 3.13 & 3.28 & $3 \cdot 16$ & 3.20 & 3.31 & $3 \cdot 12$ \\
\hline \multirow[t]{2}{*}{ Thr } & 4.84 & 0.08 & $\mathrm{LP}^{*}$ & 4.78 & $4 \cdot 86$ & 4.66 & $4 \cdot 81$ & 4.76 & 4.68 & 5.02 & 4.86 & 4.80 & 5.00 & 4.86 & $4 \cdot 86$ & 4.99 & 5.08 & 5.05 & 4.98 \\
\hline & & & HP & 4.83 & 4.83 & 4.95 & 4.85 & $5 \cdot 15$ & 4.77 & 4.90 & 4.87 & 4.50 & 4.90 & 4.90 & 4.87 & 5.02 & 4.93 & $4 \cdot 81$ & 4.99 \\
\hline \multirow[t]{2}{*}{ Val } & 4.93 & 0.23 & LP & 4.73 & 4.76 & 4.73 & 4.70 & 5.08 & 5.04 & 4.71 & 4.83 & 5.04 & 4.58 & $5 \cdot 20$ & $5 \cdot 20$ & 4.86 & 5.05 & 4.70 & 4.98 \\
\hline & & & $\mathrm{HP}$ & 4.98 & 4.82 & 4.66 & 4.68 & 4.37 & 4.82 & 5.02 & 4.84 & 4.75 & $4 \cdot 86$ & 4.86 & 4.74 & 4.83 & 4.93 & 5.04 & 4.72 \\
\hline \multirow[t]{2}{*}{ Ala } & $6 \cdot 12$ & 0.15 & LP & $6 \cdot 37$ & 6.47 & $6 \cdot 47$ & 6.57 & $6 \cdot 40$ & 6.48 & $6 \cdot 46$ & 6.45 & 6.63 & $6 \cdot 52$ & 6.49 & $6 \cdot 55$ & $6 \cdot 67$ & $6 \cdot 31$ & $6 \cdot 28$ & $6 \cdot 35$ \\
\hline & & & $\mathrm{HP}$ & $6 \cdot 20$ & 6.45 & 6.49 & 6.44 & $6 \cdot 61$ & $6 \cdot 34$ & $6 \cdot 31$ & 6.43 & 6.68 & 6.45 & 6.45 & 6.36 & $6 \cdot 38$ & $6 \cdot 35$ & $6 \cdot 27$ & 6.72 \\
\hline \multirow[t]{2}{*}{ Asp } & 9.80 & 0.11 & LP & 9.89 & 10.02 & 10.07 & $9 \cdot 73$ & 9.89 & 9.65 & $9 \cdot 74$ & 6.45 & 10.09 & 10.00 & $10 \cdot 11$ & $10 \cdot 04$ & 9.86 & 9.91 & 9.56 & 10.02 \\
\hline & & & HP & 9.90 & 6.45 & 9.92 & 9.80 & $10 \cdot 06$ & 9.74 & 9.83 & 9.86 & 9.83 & 6.45 & 6.45 & 9.87 & $10 \cdot 31$ & 10.02 & 9.95 & 9.86 \\
\hline \multirow[t]{2}{*}{ Glu } & 15.49 & 0.12 & LP & 15.92 & $15 \cdot 83$ & $15 \cdot 86$ & $15 \cdot 17$ & $15 \cdot 24$ & $15 \cdot 08$ & 14.92 & 15.42 & 15.49 & 15.43 & 15.42 & 15.63 & $15 \cdot 59$ & $15 \cdot 23$ & $15 \cdot 20$ & 15.62 \\
\hline & & & $\mathrm{HP}$ & $15 \cdot 84$ & 15.43 & 15.47 & 15.02 & 15.53 & $15 \cdot 10$ & 15.40 & 15.00 & 15.00 & 15.40 & 15.39 & $15 \cdot 22$ & $15 \cdot 76$ & 15.49 & $15 \cdot 76$ & $15 \cdot 20$ \\
\hline \multirow[t]{2}{*}{ Gly } & 7.45 & 0.21 & LP & 7.63 & 8.07 & 7.66 & 8.65 & 8.64 & 8.94 & 8.49 & 8.23 & 8.28 & 8.27 & 8.02 & 8.09 & 8.03 & 7.92 & 7.29 & 8.05 \\
\hline & & & $\mathrm{HP}^{*}$ & $7 \cdot 76$ & 8.36 & 8.64 & 8.69 & 8.86 & 8.51 & $8 \cdot 12$ & 8.46 & 8.19 & 8.06 & 8.03 & 7.99 & 7.50 & 7.92 & 7.22 & 7.97 \\
\hline \multirow[t]{2}{*}{ Pro } & 3.92 & 0.08 & LP & $4 \cdot 15$ & 4.56 & $5 \cdot 24$ & 5.00 & $4 \cdot 10$ & 4.73 & 4.69 & 4.59 & 4.69 & 4.58 & 4.51 & $4 \cdot 18$ & 4.52 & 4.55 & 4.40 & 4.08 \\
\hline & & & $\mathrm{HP}^{*}$ & 4.62 & 4.71 & 4.88 & 4.82 & 4.90 & 4.70 & 4.43 & 5.08 & 4.46 & 4.43 & 4.40 & 4.20 & 3.49 & $4 \cdot 14$ & $4 \cdot 10$ & 4.32 \\
\hline Ser & 4.59 & 0.05 & LP & 4.78 & 4.87 & 4.93 & 4.92 & 4.90 & 4.71 & 4.95 & 4.84 & 4.80 & $4 \cdot 86$ & 4.56 & 4.71 & 4.82 & 4.79 & 4.83 & 4.79 \\
\hline & & & HP & 4.58 & 4.88 & $5 \cdot 11$ & 4.94 & $5 \cdot 29$ & 4.84 & $4 \cdot 81$ & 4.82 & 4.59 & 4.79 & 4.78 & 4.74 & 4.80 & $4 \cdot 71$ & 4.59 & 4.71 \\
\hline
\end{tabular}

HP, high-protein diet; LP, low-protein diet.

"Significant $(P<0.05)$ linear increase with increasing dietary Lys level.

†Significant $(P<0.05)$ linear decrease with increasing dietary Lys level.

.

For details of procedures and diets, see Materials and methods section and Table 1 . The initial body weight of the rainbow trout fry was 0.78 (SD 0.01$) \mathrm{g}$ and water temperature was $14.5-15.5^{\circ} \mathrm{C}$. Tryptophan could not be determined with the amino acid analysis method used. 
studies have a role to play in explaining part of the relative Lys requirement variation observed in the piscine literature.

Model choice, another factor pinpointed as causing requirement variation, had an impact on the trout fry Lys requirement estimations in the present work. The BLM gave the lowest values compared to the SKM-4, especially when the requirement was defined as the Lys concentration or intake corresponding to 0.95 of the maximum response $\left(0.95 y_{\max }\right)$. Lower values with the BLM compared to a non-linear model have also been previously reported in rainbow trout $^{(1,26)}$. In a Lys requirement study, Encarnação et al. ${ }^{(4)}$ observed that relative dietary Lys requirement estimates obtained using the BLM resulted in a lower requirement value $(18 \mathrm{~g} / \mathrm{kg}$ diet) compared to a four-parameter logistic model used by Gahl et al. ${ }^{(58)}(23 \mathrm{~g} / \mathrm{kg}$ diet $)$ that usually gives a very similar requirement estimate compared to the SKM-4 with four parameters ${ }^{(26)}$. According to Bureau \& Encarnação $^{(1)}$, a value of $18 \mathrm{~g}$ Lys $/ \mathrm{kg}$ diet recommended by the National Research Council ${ }^{(27)}$ appears underestimated and this would be mainly a result of the fact that the National Research Council ${ }^{(27)}$ based the AA fish requirement recommendations on studies that used the ANOVA or the BLM approaches. The present results clearly support the experimental evidence of Encarnação et al. ${ }^{(4)}$ and Rodehutscord et al. ${ }^{(59)}$ that a Lys level of $18 \mathrm{~g} / \mathrm{kg}$ is insufficient to ensure maximum response at an optimal protein concentration in trout, whatever the model used to interpret the data. Therefore, we suggest that the recommendations of the National Research Council ${ }^{(27)}$ concerning the Lys requirements for trout as well as for salmon fry ${ }^{(60)}$ be re-evaluated.

Globally, both models fitted equally well the data (similar $r^{2}$ ). The Lys requirement estimation was less sensitive to small data modifications when estimated with the BLM or the SKM-4 with $0.90 y_{\max }$. The requirement estimated with $0.95 y_{\max }$ had a larger uncertainty than with $0.90 y_{\max }$ due to the aspect of the curve, which is almost asymptotical in that area. In effect, for this particular part of the SKM-4 curve, a small variation in $\mathrm{Y}$ induces a large variation in $\mathrm{X}$. For this reason, it is more difficult to estimate accurately the requirement with $0.95 y_{\max }$ as it is with $0.90 y_{\max }$.

For specific parts of the response curve, such as for very low Lys intakes and for the portion around the optimum, the two models provided different fit for the data. At very low Lys intakes (between zero and the maintenance level), the dietary Lys intake is replacing the amount expended in obligatory metabolism which, in the case of insufficient dietary supply, is derived from body protein breakdown. In this zone, the SKM-4 describes the overall response of the animals as sigmoidal with a positive inflection at low intakes. Therefore, it suggests a small marginal response to the lowest AA intakes (the first derivative at zero intake is zero ${ }^{(61)}$ ). In the present study, however, the efficiency of utilisation of Lys in this zone seems to be constant and close to $100 \%$. Our group recently reported a similar conclusion in the study of the threonine requirement for maintenance in Atlantic salmon (Salmo salar) fry using either the graded supplementation technique ${ }^{(53)}$ or the diet dilution procedure ${ }^{(62)}$. In view of this evidence and because it is in this intake range that the highest efficiency of utilisation is observed, we believe that the SKM-4 does not provide a good description of the fish response in this zone. Therefore, in this intake range, a linear model (BLM) seems more appropriate and it is for this reason that we used a linear regression to determine the Lys requirement for maintenance.

After the maintenance requirement to up to about $90 \%$ of the maximum response, the animals in the present experiment responded to an increase in Lys intake and in Lys dietary concentration with a similar linear increase in protein and Lys gains at both protein levels. Both models were deemed adequate for this portion and for both LP and HP levels.

A diminishing returns portion of the response curve was apparent for Lys levels above $21 \mathrm{~g} / \mathrm{kg} \mathrm{DM}$ (diet HP7) for the HP diets. Therefore, the SKM-4 most accurately described this part of the response curve around the requirement at this protein level. However for the LP diets there was no evidence of diminishing returns in this part of the curve and the BLM fitted the data as well as the SKM-4. This difference in the form of the curve around the requirement between the HP and LP levels could be attributed to the suboptimal protein level of the LP diets. Indeed, the present study confirmed that the LP diets were suboptimal in terms of digestible protein concentration because, when Lys was supplied in sufficient quantities (above the total requirement for growth and maintenance), trout performances were higher for the HP diets compared to the LP diets in terms of weight gain, feed efficiency, protein gain and Lys gain. In the LP diets, another AA may become co-limiting, restraining abruptly the response of the animals. In this case, Lys would become in excess and consequently be oxidised, reducing the Lys utilisation efficiency (Fig. 3). In conclusion, neither of the two models that were tested seemed to provide an appropriate description of all parts of the response curve, although both provide a good fit to the data over one or two particular regions. To assess the possible influence the model choice can have on the Lys requirement estimation, the percentage of difference was calculated for the three model types between themselves (BLM - SKM-4(0.90), BLM - SKM-4(0.95) and SKM-4(0.90) - SKM-4(0.95)). This was done for all response criteria (liveweight gain, protein gain and Lys gain), all protein levels (LP and HP) and all modes of expression (Lys concentration and Lys intake). It led to a range of variation of $1-135 \%$ and demonstrated clearly how great an influence the model choice may have.

The response criterion selection highly influenced the calculated Lys requirements in the present paper. In our study, $29.4 \mathrm{~g}$ Lys $/ \mathrm{kg}$ DM were required to achieve $95 \%$ of the maximum response in Lys gain whereas only $24 \mathrm{~g} / \mathrm{kg}$ DM were required to achieve $95 \%$ of the maximum response in body weight gain, for trout fed the HP diet and with the SKM-4. Several studies have demonstrated that the choice of the dependent variable is an important factor affecting the shape of the dose-response curve and hence the calculated AA requirement ${ }^{(63)}$. In the present study, the Lys requirement varied with the selected response criterion (weight gain, protein gain or Lys gain) and suggests that body composition is affected by dietary Lys concentration. Indeed, the present results showed a linear increase of both nitrogen whole-body composition (g/100 g liveweight) and Lys concentration of whole-body protein (g/100 g AA) (Table 9) with dietary Lys concentration. This effect has already been reported in rainbow trout ${ }^{(4,64)}$, Atlantic salmon fry ${ }^{(65)}$, pigs ${ }^{(66-68)}$, chicks ${ }^{(69)}$ and rats ${ }^{(70)}$. 
Interestingly, in the present experiment the whole-body histidine concentration increased with increasing Lys level, at both protein concentrations. Recently, Bodin et al. ${ }^{(71)}$ reported this observation with histidine when rainbow trout and Atlantic salmon fry were fed threonine-deficient diets. Their results suggest that these changes are not related specifically to individual AA deficiencies but are simply a consequence of slow growth. Therefore, whole-body histidine concentration appears to be a promising indicator of normal growth rate for fish. In addition, the data imply that the deficiency of an individual AA, such as Lys, does not necessarily entail a proportionate loss of body protein and a commensurately negative nitrogen balance. These changes presumably result from alterations in the relative amounts of different proteins, whose rates of synthesis or breakdown are in turn sensitive to the dietary AA supply ${ }^{(72)}$. However, the identification of the proteins involved and the mechanism for the control of their turnover are yet to be discovered. The percentage of difference was also calculated for the three response criteria between themselves (liveweight gain, protein gain and Lys gain). This was done for all models (BLM, SKM-4(0.90), SKM-4(0.95), all protein levels (LP and HP) and all modes of expression (Lys concentration and Lys intake). It led to a range of variation of $4-48 \%$ and showed the impact the response criterion may have on requirement estimation.

The manner of expressing the requirement is the last factor influencing Lys requirement estimations to be addressed. In the present paper, the differences in the Lys requirements between the different models used were more pronounced when Lys intake rather Lys concentration was used as the independent variable (Table 7). For example, when Lys gain ( $\mathrm{g} / \mathrm{kg}$ MBW per $\mathrm{d}$ ) was plotted against Lys intake, the absolute Lys requirement was calculated to be $0.19 \mathrm{~g} / \mathrm{kg} \mathrm{MBW}$ per $\mathrm{d}$ with the BLM but $0.32 \mathrm{~g} / \mathrm{kg}$ MBW per d with the SKM$4(0.95)$ at the HP level, i.e. a variation of $72 \%$ (when calculated with seven decimals). These differences between the different models were considerably reduced (variation of $0.8 \%$ ) if the definition of the Lys requirement was the Lys concentration for 0.90 of the maximum response $\left(0.90 y_{\max }\right)$. For rainbow trout, and concerning other ways of expressing the requirement, Hauler $\&$ Carter $^{(2)}$ found more variation in the Lys requirement expressed as a percentage of the dietary protein $(136 \%)$ than as a percentage of the diet, while for other species, Cowey ${ }^{(5)}$ observed that AA requirements expressed as a percentage of dietary protein reduced the intra-species variation in the AA requirement estimations. We suggest that the best manner of expressing the Lys requirement depends on the available information. When the digestibility of the nutrients, the expected growth rates and the expected feed efficiency of a given diet are known (which is the case for most fish producers), the results of the present study demonstrate that the Lys requirement for rainbow trout fry is best expressed in absolute terms $(\mathrm{g} / \mathrm{kg}$ MBW per d) since the dietary protein level did not influence significantly the absolute Lys requirement estimation. However, if the aforementioned parameters are not known (which is the case for most feed manufacturers), we suggest that Lys requirement be expressed in relative terms. Of the different possibilities, it is best expressed as a percentage of dietary protein since the dietary protein level did not significantly affect the relative Lys requirement estimation expressed in $\mathrm{g} / 100 \mathrm{~g}$ protein for the rainbow trout fry in the present study. It would be interesting to undertake similar studies on other fish sizes and species in order to arrive at a consensus concerning the appropriate manner of expressing AA requirements.

The dietary protein levels did not affect the maintenance requirement for Lys in rainbow trout fry. In the present experiment and based on Lys accretion, the Lys requirement for maintenance of rainbow trout fry grown at $14 \cdot 5-15 \cdot 5^{\circ} \mathrm{C}$ was higher (21 (SD 2) $\mathrm{mg}$ Lys/kg MBW per d) than the reported value for rainbow trout juveniles $(11 \mathrm{mg}$ Lys $/ \mathrm{kg}$ MBW per $\left.\mathrm{d}^{(59)}\right)$, but similar to the Lys requirement of Atlantic salmon fry (20 mg Lys/kg MBW per d, based on $\mathrm{N}$ accretion, or $28 \mathrm{mg}$ Lys/kg MBW per d based on Lys accretion ${ }^{(28)}$ ) grown at $14.7^{\circ} \mathrm{C}$ in very similar conditions as the ones of the present study. In the present study, the estimate of the Lys requirement for maintenance in rainbow trout fry is in the range of values reported for terrestrial animals, i.e. pigs $\left(25^{(73)}\right.$, $\left.36^{(34)}\right)$, rats $\left(34^{(74)}, 10^{(75)}, 32^{(22)}\right)$ or for man $\left(33^{(76)}\right)$. Since the protein requirement for maintenance is considerably higher (about five times) in these terrestrial animals ${ }^{(34)}$, it appears that the Lys maintenance requirement represents a much higher part of the protein maintenance requirement in trout fry ${ }^{(65)}$ compared to terrestrial animals.

In conclusion, the present study shows that: (1) the relative Lys requirement of rainbow trout estimated with the BLM increased from $16 \cdot 8 \mathrm{~g} / \mathrm{kg} \mathrm{DM}$ at LP level $(310 \mathrm{~g} / \mathrm{kg} \mathrm{DM})$ to $23.4 \mathrm{~g} / \mathrm{kg}$ DM at HP level $(469 \mathrm{~g} / \mathrm{kg} \mathrm{DM})$; (2) the absolute Lys requirement expressed in terms of intake $(\mathrm{g} / \mathrm{kg} \mathrm{MBW}$ per d) and the relative Lys requirement expressed in terms of dietary protein $(\mathrm{g} / 100 \mathrm{~g}$ protein) remained unaffected by the digestible protein content in the diet; (3) both the model and the response criterion chosen had a considerable impact on the relative Lys requirement; (4) the digestible protein content did not affect the Lys requirement for maintenance (21 mg Lys/kg MBW per d).

\section{Acknowledgements}

The authors thank Marc Michotte for expert technical assistance and Yves Beckers (Faculté universitaire des Sciences agronomiques de Gembloux, Gembloux, Belgium) for the use of the bomb calorimeter. X. R. designed the study. N. B and B. G. did the data analysis. C. D. and S. D. S. did the AA analysis. N. B., X. R., Y. L. and T. A. contributed to the drafting of the paper. There are no financial or other contractual agreements that might cause conflicts of interest or be perceived as causing conflicts of interest. The authors are grateful to the Université catholique de Louvain for funding this project and to the helpful remarks of the anonymous referees.

\section{References}

1. Bureau DP \& Encarnação PM (2006) Adequately defining the amino acid requirements of fish: the case example of lysine. In Avances en Nutrición Acuicola, VIII Symposium Internacional de Nutrición Acuicola, pp. 29-54 [LEC Suárez, DR Marie, MT Salazar, MGN López, DAV Cavazos, ACP Cruz and AG Ortega, editors]. Nuevo León, Mexico: Universidad Autónoma de Nuevo León. 
2. Hauler RC \& Carter CG (2001) Re-evaluation of the quantitative dietary lysine requirements of fish (review paper). Rev Fish Sci 9, 133-163.

3. Hauler RC \& Carter CG (2001) Lysine deposition responds linearly to marginal lysine intake in Atlantic salmon (Salmo salar L.) parr. Aquacult Res 32, 147-156.

4. Encarnação P, De Lange C, Rodehutscord M, et al. (2004) Diet digestible energy content affects lysine utilization, but not dietary lysine requirements of rainbow trout (Oncorhynchus mykiss) for maximum growth. Aquaculture 235, 569-586.

5. Cowey CB (1994) Amino acid requirements of fish: a critical appraisal of present values. Aquaculture 124, 1-11.

6. Shearer KD (2000) Experimental design, statistical analysis and modelling of dietary nutrient requirement studies for fish: a critical review. Aquacult Nutr 6, 91-102.

7. Grau CR (1948) Effect of protein level on the lysine requirement of the chick. J Nutr 36, 99-108.

8. Almquist HJ (1949) Amino acid balance at super-normal dietary levels. Proc Soc Exp Biol Med 72, 179-180.

9. Brinegar MJ, Williams HH, Ferris FH, et al. (1950) The lysine requirement for the growth of swine. J Nutr 42, 129-138.

10. Grau CR \& Kamei M (1950) Amino acid imbalance and the growth requirements for lysine and methionine. J Nutr 41, 89-101.

11. Becker DE, Jensen AH, Terrill SW, et al. (1957) The isoleucine requirement of weanling swine fed two protein levels. J Anim Sci 16, 26-34.

12. Bressani R \& Mertz ET (1958) Relationship of protein level to the minimum lysine requirement of the rat. J Nutr $\mathbf{6 5}, 481-491$.

13. McWard GW, Becker DE, Norton HW, et al. (1959) The lysine requirement of weanling swine at two levels of dietary protein. J Anim Sci 18, 1059-1066.

14. Baker DH, Katz RS \& Easter RA (1975) Lysine requirement of growing pigs at two levels of dietary protein. J Anim Sci 40, $851-856$.

15. Milner JA (1981) Lysine requirements of the immature dog. J Nutr 111, 40-45.

16. Morris TR, Alazzawi K, Gous RM, et al. (1987) Effects of protein concentration on responses to dietary lysine by chicks. Br Poult Sci 28, 185-195.

17. Mendonca CX \& Jensen LS (1989) Influence of protein concentration on the sulphur-containing amino acid requirement of broiler chickens. Br Poult Sci 30, 889-898.

18. Almquist HJ (1972) Proteins and Amino Acids in Animal Nutrition. New York: S.B. Penick.

19. Forbes RM, Baughan L \& Norton HW (1955) Studies on the utilization of dietary isoleucine by the growing albino rat. J Nutr 57, 593-598.

20. Klay RF (1964) The lysine requirement for growth of the pig at four protein levels, AbstrJ Anim Sci 23, 881.

21. Sowers JE \& Meade RJ (1972) Effect of protein level on the threonine requirement of the pig, AbstrJ Anim Sci 35, 224.

22. National Research Council (1995) Nutrient Requirements of Laboratory Animals. Washington, DC: National Academic Press.

23. Robbins KR, Norton HW \& Baker DH (1979) Estimation of nutrient requirements from growth data. J Nutr 109, 1710-1714.

24. Morgan PH, Mercer LP \& Flodin NW (1975) General model for nutritional responses of higher order mechanisms. Proc Natl Acad Sci U S A 72, 4327-4331.

25. Rodehutscord M, Borchert F, Gregus Z, et al. (2000) Availability and utilisation of free lysine in rainbow trout (Oncorhynchus mykiss). 1. Effect of dietary crude protein level. Aquaculture 187, 163-176.

26. Rodehutscord M \& Pack M (1999) Estimates of essential amino acid requirements from dose-response studies with rainbow trout and broiler chicken: effect of mathematical model. Arch Anim Nutr Arch Tierernahr 52, 223-244.

27. National Research Council (1993) Nutrient Requirements of Fish. Washington, DC: National Academic Press.

28. Abboudi T, Mambrini M, Ooghe W, et al. (2006) Protein and lysine requirements for maintenance and for tissue accretion in Atlantic salmon (Salmo salar) fry. Aquaculture 261, 369-383.

29. Mambrini M \& Kaushik SJ (1994) Partial replacement of dietary protein nitrogen with dispensable amino acids in diets of Nile tilapia, Oreochromis niloticus. Comp Biochem Physiol A Mol Integr Physiol 109, 469-477.

30. Choubert G, Delanoue J \& Luquet P (1982) Digestibility in fish: improved device for the automatic collection of feces. Aquaculture 29, 185-189.

31. Nang Thu TT, Parkouda C, De Saeger S, et al. (2007) Comparison of the lysine utilization efficiency in different plant protein sources supplemented with L-lysine. $\mathrm{HCl}$ in rainbow trout (Oncorhynchus mykiss) fry. Aquaculture 272, 477-488.

32. Czarnocki J, Sibbald IR \& Evans EV (1961) The determination of chromic oxide in samples of feed and excreta by acid digestion and spectrophotometry. Can J Anim Sci 41, 167-179.

33. Fenton TW \& Fenton M (1979) An improved procedure for the determination of chromic oxide in feed and faeces. Can J Anim Sci 59, 631-634.

34. Fuller MF, McWilliam R, Wang TC, et al. (1989) The optimum dietary amino acid pattern for growing pigs. 2. Requirements for maintenance and for tissue protein accretion. Br J Nutr 62, 255-267.

35. Edwards HM, Baker DH, Fernandez SR, et al. (1997) Maintenance threonine requirement and efficiency of its use for accretion of whole-body threonine and protein in young chicks. $\mathrm{Br}$ J Nutr 78, 111-119.

36. Mercer LP (1982) The quantitative nutrient-response relationship. J Nutr 112, 560-566.

37. Mercer LP, May HE \& Dodds SJ (1989) The determination of nutritional requirements in rats: mathematical modeling of sigmoidal, inhibited nutrient-response curves. J Nutr 119, 1465-1471.

38. Rodehutscord M, Jacobs S, Pack M, et al. (1995) Response of rainbow trout (Oncorhynchus mykiss) growing from 50 to $170 \mathrm{~g}$ to supplements of either L-arginine or L-threonine in a semipurified diet. $J$ Nutr 125, 970-975.

39. Heger J \& Frydrych Z (1985) Efficiency of utilisation of essential amino acids in growing rats at different levels of intake. $\mathrm{Br} \mathrm{J}$ Nutr 54, 499-508.

40. Venables W \& Ripley B (2002) Modern Applied Statistics with $S$. New York: Springer.

41. Efron B \& Tibshirani RJ (1993) An Introduction to the Bootstrap. New York: Chapman and Hall.

42. Krogdahl Å, Sundby A \& Olli JJ (2004) Atlantic salmon (Salmo salar) and rainbow trout (Oncorhynchus mykiss) digest and metabolize nutrients differently. Effects of water salinity and dietary starch level. Aquaculture 229, 335-360.

43. Frøystad MK, Lilleeng E, Sundby A, et al. (2006) Cloning and characterization of alpha-amylase from Atlantic salmon (Salmo salar L.). Comp Biochem Physiol A Mol Integr Physiol 145, 479-492.

44. Plisetskaya EM, Fabbri E, Moon TW, et al. (1993) Insulin-binding to isolated hepatocytes of Atlantic salmon and rainbow trout. Fish Physiol Biochem 11, 401-409.

45. Párrizas M, Planas J, Plisetskaya EM, et al. (1994) Insulin binding and receptor tyrosine kinase-activity in skeletal-muscle of carnivorous and omnivorous fish. Am J Physiol 266, R1944-R1950.

46. Gutiérrez J, Åsgård T, Fabbri E, et al. (1991) Insulin-receptor binding in skeletal-muscle of trout. Fish Physiol Biochem 9, $351-360$. 
47. Wilson RP (1994) Utilization of dietary carbohydrate by fish. Aquaculture 124, 67-80.

48. Bucking C \& Wood CM (2005) Renal regulation of plasma glucose in the freshwater rainbow trout. J Exp Biol 208, 2731-2739.

49. Hilton JW \& Atkinson JL (1982) Response of rainbow trout (Salmo gairdneri) to increased levels of available carbohydrate in practical trout diets. Br J Nutr 47, 597-607.

50. Hilton JW \& Dixon DG (1982) Effect of increased liver glycogen and liver weight on liver function in rainbow trout, Salmo gairdneri Richardson - recovery from anesthesia and plasma S-35-sulphobromophthalein clearance. J Fish Dis 5, 185-195.

51. Dixon DG \& Hilton JW (1985) Effects of available dietary carbohydrate and water temperature on the chronic toxicity of waterborne copper to rainbow trout (Salmo gairdneri). Can $J$ Fisheries Aquat Sci 42, 1007-1013.

52. Storebakken T, Shearer KD, Refstie S, et al. (1998) Interactions between salinity, dietary carbohydrate source and carbohydrate concentration on the digestibility of macronutrients and energy in rainbow trout (Oncorhynchus mykiss). Aquaculture 163, 347-359.

53. Rollin X, Wauters JB, Bodin N, et al. (2006) Maintenance threonine requirement and efficiency of its use for accretion of whole-body threonine and protein in Atlantic salmon (Salmo salar L.) fry. Br J Nutr 95, 234-245.

54. Katz RS, Baker DH, Sasse CE, et al. (1973) Efficacy of supplemental lysine, methionine and rolled oats for weanling pigs fed a low-protein corn-soybean meal diet. J Anim Sci 37, $1165-1168$

55. Mercer LP, Watson DF \& Ramlet JS (1981) Control of food intake in the rat by dietary protein concentration. $J$ Nutr 111, $1117-1123$

56. Finke MD, Defoliart GR \& Benevenga NJ (1987) Use of simultaneous curve fitting and a 4-parameter logistic model to evaluate the nutritional quality of protein-sources at growth-rates of rats from maintenance to maximum gain. J Nutr 117, 1681-1688.

57. Tacon AGJ \& Cowey CB (1985) Protein and amino acid requirements. In Fish Energetics: New Perspectives, pp. 155-183 [P Tyler and P Calow, editors]. London: Croom Helem.

58. Gahl MJ, Finke MD, Crenshaw TD, et al. (1991) Use of a 4-parameter logistic equation to evaluate the response of growing rats to ten levels of each indispensable amino acid. J Nutr 121, $1720-1729$

59. Rodehutscord M, Becker A, Pack M, et al. (1997) Response of rainbow trout (Oncorhynchus mykiss) to supplements of individual essential amino acids in a semipurified diet, including an estimate of the maintenance requirement for essential amino acids. J Nutr 127, 1166-1175.

60. Rollin X, Mambrini M, Abboudi T, et al. (2003) The optimum dietary indispensable amino acid pattern for growing Atlantic salmon (Salmo salar L.) fry. Br J Nutr 90, 865-876.
61. Fuller MF \& Garthwaite P (1993) The form of response of body protein accretion to dietary amino acid supply. J Nutr $\mathbf{1 2 3}$, 957-963.

62. Abboudi T, Ooghe W, Larondelle Y, et al. (2007) Determination of the threonine requirement for maintenance in Atlantic salmon (Salmo salar L.) fry with the diet dilution procedure. Aquacult Nutr 13, 281-290.

63. Finke MD, Defoliart GR \& Benevenga NJ (1987) Use of a 4-parameter logistic model to evaluate the protein quality of mixtures of Mormon cricket meal and corn gluten meal in rats. J Nutr 117, 1740-1750.

64. Encarnação P, De Lange C \& Bureau DP (2006) Diet energy source affects lysine utilization for protein deposition in rainbow trout (Oncorhynchus mykiss). Aquaculture 261, 1371-1381.

65. Rollin X (1999) A critical study of the indispensable amino acid requirements in Atlantic salmon (Salmo salar L.) fry. PhD Thesis, Université catholique de Louvain.

66. Batterham ES, Andersen LM, Baigent DR, et al. (1990) Utilization of ileal digestible amino acids by growing pigs: effect of dietary lysine concentration on efficiency of lysine retention Br J Nutr 64, 81-94.

67. Gahl MJ, Crenshaw TD \& Benevenga NJ (1992) Amino acid composition and retention in growing pigs fed graded levels of lysine, AbstrJ Anim Sci 70, Suppl. 1, 66.

68. Gahl MJ, Crenshaw TD \& Benevenga NJ (1994) Diminishing returns in weight, nitrogen, and lysine gain of pigs fed 6 levels of lysine from 3 supplemental sources. J Anim Sci 72, 3177-3187.

69. Edwards HM, Fernandez SR \& Baker DH (1999) Maintenance lysine requirement and efficiency of using lysine for accretion of whole-body lysine and protein in young chicks. Poult Sci 78, $1412-1417$.

70. Gahl MJ, Finke MD, Crenshaw TD, et al. (1996) Efficiency of lysine or threonine retention in growing rats fed diets limiting in either lysine or threonine. J Nutr 126, 3090-3099.

71. Bodin N, Mambrini M, Wauters J-B, et al. (2008) Threonine requirements for rainbow trout (Oncorhynchus mykiss) and Atlantic salmon (Salmo salar) at the fry stage are similar. Aquaculture 274, 353-365.

72. Fuller MF \& Garlick PJ (1994) Human amino acid requirements can the controversy be resolved? Annu Rev Nutr 14, 217-241.

73. Baker DH, Becker DE, Norton HW, et al. (1966) Some qualitative amino acid needs of adult swine for maintenance. J Nutr $\mathbf{8 8}$, 382-390.

74. Said AK \& Hegsted DM (1970) Response of adult rats to low dietary levels of essential amino acids. J Nutr 100, 1363-1375.

75. Dreyer JJ (1975) Biological assessment of protein quality: essential amino acid requirements of young rats in certain states of nitrogen balance. S Afr Med J 49, 1667-1673.

76. Rose WC (1957) The amino acid requirements of adult man Nutr Abstr Rev 27, 631-647. 